\title{
Recycled crust in the Galápagos Plume source at 70 Ma:
} Implications for plume evolution

4 Jarek Trela ${ }^{1}$, Chris Vidito ${ }^{2}$, Esteban Gazel ${ }^{1 *}$, Claude Herzberg² ${ }^{2}$ Cornelia Class ${ }^{3}$, William Whalen ${ }^{1}$, Brian Jicha ${ }^{4}$, Michael Bizimis $^{5}$, Guillermo E. Alvarado ${ }^{6}$

6

1. Department of Geosciences, Virginia Tech, Blacksburg, VA 24061, USA

2. Earth and Planetary Sciences, Rutgers University, Piscataway, NJ 08854, $U S A$ 10964, USA 53706, USA

5. Department of Earth and Ocean Sciences, University of South Carolina, Columbia, SC 29208, USA Sismologica y Volcanica, Apdo 10032-1000, Costa Rica

*Corresponding author: egazel@vt.edu

\section{Revised manuscript for EPSL}




\section{ABSTRACT}

25 Galápagos plume-related lavas in the accreted terranes of the Caribbean and

26 along the west coast of Costa Rica and Panama provide evidence on the evolution of

27 the Galápagos mantle plume, specifically its mantle temperature, size and

28 composition of heterogeneities, and dynamics. Here we provide new ${ }^{40} \mathrm{Ar} /{ }^{39} \mathrm{Ar}$ ages,

29 major and trace element data, $\mathrm{Sr}-\mathrm{Nd}-\mathrm{Pb}$ isotopic compositions, and high-precision

30 olivine analyses for samples from the Quepos terrane (Costa Rica) to closely

31 examine the transitional phase of the Galápagos Plume from Large Igneous Province

32 (LIP) to ocean island basalt (OIB) forming stages. The new ages indicate that the

33 record of Quepos volcanism began at $70 \mathrm{Ma}$ and persisted for $10 \mathrm{Ma}$. Petrological

34 evidence suggests that the maximum mantle potential temperature $\left(T_{p}\right)$ of the

35 plume changed from $\sim 1650^{\circ}$ to $\sim 1550^{\circ} \mathrm{C}$ between $90-70 \mathrm{Ma}$. This change correlates

36 with a dominant pyroxenite component in the Galapagos source as indicated by high

$37 \mathrm{Ni}$ and $\mathrm{Fe} / \mathrm{Mn}$ and low $\mathrm{Ca}$ olivines relative to those that crystallized in normal

38 peridotite derived melts. The decrease in $\mathrm{T}_{\mathrm{p}}$ also correlates with an increase in high-

39 field strength element enrichments, e.g., $\mathrm{Nb} / \mathrm{Nb}^{*}$, of the erupted lavas. Radiogenic

40 isotope ratios $(\mathrm{Nd}-\mathrm{Pb})$ suggest that the Quepos terrane samples have intermediate

41 (Central Domain) radiogenic signatures. The Galápagos plume at 70 Ma represents

42 elevated pyroxenite melt productivity relative to peridotite in a cooling

43 lithologically heterogeneous mantle.

\section{KEYWORDS}

45 Galápagos plume, mantle evolution, olivine chemistry, source composition, LIP-OIB 


\section{1. INTRODUCTION}

48 The initial melting of mantle plumes produces unparalleled volumes $(5-40 \mathrm{x}$

$4910^{6} \mathrm{~km}^{3}$ ) of lava that form continental flood basalts and oceanic plateaus, which

50 represent the most significant igneous structures on Earth (e.g., Coffin and Eldholm,

51 1994; Mahoney and Coffin, 1997; Saunders, 2005; Coffin et al., 2006). This type of

52 intra-plate magmatism originates at a deep thermal boundary layer below the upper

53 mantle, (possibly the core-mantle boundary, e.g., Morgan, 1972; Tolstikhin and

54 Hofmann, 2005; Torvisk et al., 2010; Burke et al., 2011). During ascent, a plume may

55 develop a volumetrically large "head", followed by a narrower conduit or "tail".

56 Geodynamic models suggest that melting of a 500-2000 km wide plume head

57 (Arndt, 2000) forms large igneous provinces (LIPs), characterized by high degrees

58 of partial melting, high mantle potential temperatures $\left(\mathrm{T}_{\mathrm{p}}\right)$, and widespread lava

59 flows (>105 $\mathrm{km}^{2}$ ) (Richards et al., 1989; Coffin and Eldholm, 1994, Herzberg and

60 Gazel, 2009). These events were sometimes so large that they affected

61 environmental change leading to catastrophic mass extinctions or oceanic anoxic

62 events (e.g., Courtillot and Renne, 2004; Kerr, 2005; Blackburn et al., 2013).

63 Subsequent melting of a plume conduit will form ocean island basalts (OIBs), which

64 may manifest themselves as tracks of linear ocean islands and seamount chains.

65 Most older LIPS were hotter and melted more extensively than their younger OIB

66 counterparts (Herzberg and Gazel, 2009).

67 The Galápagos hotspot provides an exceptional opportunity to reconstruct

68 plume evolution due to the on-land accessibility of LIP terranes in the Caribbean

69 and Costa Rica (Alvarado et al., 1997; Denyer and Gazel, 2009; Loewen et al., 2013) 
70 and accreted OIB terranes along the west coast of Panama and Costa Rica (Hoernle

71 et al., 2002). Recent petrological studies suggested that the Caribbean LIP (CLIP)

72 melted more extensively and at higher temperatures than lavas from the modern

73 Galápagos Islands (Herzberg and Gazel, 2009). The maximum $T_{p}$ of the plume was

$74 \sim 1620{ }^{\circ} \mathrm{C}$ during the Cretaceous and cooled to $\sim 1500{ }^{\circ} \mathrm{C}$ at present time at a rate of

$75 \sim 1{ }^{\circ} \mathrm{C} / \mathrm{Ma}$ assuming a linear decrease (Herzberg and Gazel, 2009). Therefore,

76 understanding the evolution of the Galápagos mantle plume has significant global

77 implications for understanding mantle dynamics.

78 The amount, age, and contribution of subducted slab sources (eclogite, 79 pyroxenite, or refertilized peridotite) fingerprinted in mantle plume geochemistry 80 are also important. Although a recycled crust signature has been identified in 81 plumes through the use of radiogenic isotopes and trace-element signatures (e.g., 82 Zindler and Hart, 1986; Hofmann, 1997; Chauvel et al., 2008) and more recently 83 through the use of major element signatures (e.g., Jackson and Dasgupta, 2008;

84 Shorttle and Maclennan, 2011; Jackson et al., 2012) and numerical models (Ballmer

85 et al., 2013) the exact nature of geochemical exchanges and mixing of pyroxenite 86 with mantle end members requires further investigation. Global scale recycling of 87 crustal material undoubtedly plays a key role in the development and evolution of 88 deep geochemical reservoirs as well as affecting the thermodynamic cooling of

89 Earth. Furthermore, when compared with a primitive mantle reference, typical OIB

90 trace element signatures show positive high field strength element (e.g., $\mathrm{Nb}$ and $\mathrm{Ta}$ )

91 anomalies, suggesting a subducted slab reservoir in the mantle (McDonough, 1991;

92 Rudnick et al., 2000; Kamber and Collerson, 2000; Jackson et al., 2008). This 
93 reservoir could represent the mantle domain component common in all plumes

94 (e.g., C, FOZO) (Zindler and Hart, 1986; Hart et al., 1992; Stracke et al., 2005).

95 Our objective is to characterize the sources of the lavas present in the Quepos

96 terrane and their effect on plume evolution during the important LIP-OIB transition.

97 This "transition" marks a major decrease in the magmatic productivity when head

98 stage melting ceases and tail stage melting begins during a plume's evolution. In this

99 study we use integrated petrological, geochemical, isotopic, and high-precision

100 olivine geochemical analyses to compare our new results to preexisting data sets to

101 show a decrease in $\mathrm{T}_{\mathrm{p}}$ evident in the Quepos lavas that corresponds to a dominant

102 pyroxenite component in the Galápagos Plume.

103

\section{2. BACKGROUND}

105 The formation of the Caribbean Large Igneous Province (CLIP) began 90 Ma

106 with the incipient melting of the Galápagos plume head (Duncan and Hargraves,

107 1984; Richards et al., 1989; Pindel and Barrett, 1990; Kerr, et al., 1996a; Kerr et al.,

108 1996b; Hauff et al., 1997; Sinton et al., 1997; Hauff et al., 2000a;). The Caribbean

109 plate represents an over-thickened section of oceanic crust (up to $20 \mathrm{~km}$ ) and is

110 interpreted as the product Galápagos plume head melting (Duncan and Hargraves,

111 1984; Hauff et al., 1997, 2000a,b; Sinton et al., 1998; Kerr et al., 1996a; Hoernle et

112 al., 2002, 2004). The CLIP then migrated northeast with the Farallon Plate where it

113 collided with the Greater Antilles Arc (e.g., Duncan and Hargraves, 1984; Hauff et al.,

114 2000; Geldmacher et al., 2003, Gazel et al., 2011). This collision triggered a reversal

115 in subduction polarity, which initiated subduction along the western edge of the 
116 CLIP margin (Duncan and Hargraves, 1984; Geldmacher et al., 2003). The reversal in

117 polarity facilitated the migration of the CLIP farther northeast between the

118 converging North and South Americas between Late Cretaceous to Tertiary time

119 (e.g., Duncan and Hargraves, 1984; Hauff et al., 2000a; Hoernle et al., 2002;

120 Geldmacher et al., 2003).

121 Petrological and geochemical research of the Burica, Osa, and Quepos

122 terranes in western Costa Rica (Fig. 1) together with Azuero and Sona terranes in

123 Panama, provide strong evidence that these areas represent accreted Galápagos OIB

124 terranes, which resulted from melting of the plume tail post CLIP formation (Hauff

125 et al., 2000a; Hoernle et al., 2002; Denyer and Gazel, 2009). These terranes are

126 markedly younger than CLIP related lavas (85-95 Ma) with ${ }^{40} \mathrm{Ar} /{ }^{39} \mathrm{Ar}$ ages between

127 65-40 Ma and represent ancestral Galápagos plume tail segments accreted to

128 Central America (Sinton et al., 1997; Hauff et al., 2000a; Hoernle et al., 2002).

129 Around 23 Ma the Farallon Plate began spreading to form the Nazca and Cocos

130 plates (e.g., Lonsdale, 2005). During the next 20 Ma the Galápagos hotspot and the

131 Cocos-Nazca ridge experienced a series of complex interactions (Werner et al.,

132 2003). The ridge-hotspot interactions subsequently formed the Cocos and Carnegie

133 aseismic ridges located on the northeastward and eastward migrating Cocos and

134 Nazca Plates respectively.

135 The present day Galápagos archipelago is currently divided into four

136 domains, characterized by unique isotopic variations in $\mathrm{Nd}-\mathrm{Sr}-\mathrm{Pb}$ and ${ }^{3} \mathrm{He} /{ }^{4} \mathrm{He}$

137 (Hoernle et al., 2000; Harpp and White, 2001). The Eastern Domain represents the

138 most depleted isotopic end-member (Hoernle et al., 2000; Harpp and White, 2001) 
139 with compositions similar mid ocean ridge basalt (MORB). Lavas from Floreana

140 define the most isotopically enriched end member (Southern Domain) with high

141 radiogenic ${ }^{87} \mathrm{Sr} /{ }^{86} \mathrm{Sr}$ and ${ }^{206} \mathrm{~Pb} /{ }^{204} \mathrm{~Pb}$ ratios (Harpp and White, 2001). Lavas in the

142 Wolf-Darwin Lineament (Northern Domain) typically display minor ${ }^{207} \mathrm{~Pb}$ and ${ }^{208} \mathrm{~Pb}$

143 enrichments and ${ }^{3} \mathrm{He} /{ }^{4} \mathrm{He}$ ratios between 8.8-6.9 R/R $(\mathrm{Rarpp}$ and White, 2001;

144 Vidito et al., 2013) though they are depleted in ${ }^{87} \mathrm{Sr} /{ }^{86} \mathrm{Sr}$ and ${ }^{206} \mathrm{~Pb} /{ }^{204} \mathrm{~Pb}$ relative to

145 Floreana lavas (Harpp and White, 2001). Islands in the Central Domain (e.g.,

146 Fernandina) most likely resemble the true "plume" composition and show

147 intermediate enrichments in $\mathrm{Sr}, \mathrm{Nd}, \mathrm{Pb}$ (Harpp and White, 2001) with high ${ }^{3} \mathrm{He} /{ }^{4} \mathrm{He}$

148 (up to $30.3 \mathrm{R} / \mathrm{R}_{\mathrm{A}}$; Kurz et al., 2014).

149 The Quepos terrane (focus of this study) is one of six fault-bounded oceanic

150 igneous terranes located on the Pacific Costa Rican coast (Fig. 1). An intra-plate

151 Galápagos origin is now generally accepted to explain the formation of Quepos

152 based on petrological evidence, field-based observations, and trace element data

153 and represents the oldest accreted segments of the Galápagos OIB stage (Frisch et

154 al., 1992; Hauff et al., 1997; Denyer and Gazel, 2009). The lava stratigraphy of

155 Quepos is dominated by a transitional tholeiitic to alkaline series with incompatible

156 trace element patterns indicative of an OIB source with a clear Galápagos isotopic

157 signature (Hauff et al., 2000; Geldmacher et al., 2003).

159 3. MATERIALS AND METHODS

160 Picrite, diabase, and basalt samples were collected in the Quepos terrane,

161 from in-situ outcrops or fresh, meter-size boulders along the shoreline to take 
162 advantage of active surf erosion exposures. Sample locations can be found in Table 163 S1A in the Supplementary Materials.

164 At the University of Wisconsin-Madison Rare Gas Geochronology Laboratory, $165{ }^{40} \mathrm{Ar} /{ }^{39} \mathrm{Ar}$ incremental heating experiments were conducted on groundmass and 166 mineral separates using a 25 Watt $\mathrm{CO}_{2}$ laser and analyzed using a MAP 215-50 167 following the procedures in Jicha and Brown (2014). Isotope data was reduced 168 using ArArCalc software version 2.5 (http://earthref.org/ArArCALC/). Ages are 169 reported with $2 \sigma$ uncertainties (includes the J uncertainty) and are calculated 170 relative to a Fish Canyon standard age of 28.201 \pm 0.046 Ma (Kuiper et al., 2008) 171 and a value for $\lambda^{40} \mathrm{~K}$ of $5.463 \pm 0.107 \times 10^{-10} \mathrm{yr}^{-1}$ (Min et al., 2000) (Supplementary 172 Tables S2A-E).

173 Alteration-free rock chips were selected under stereoscopic microscope and 174 powdered in an alumina mill at the Department of Geosciences at Virginia Tech. 175 From these powders, whole rock major and trace element compositions were 176 collected at Washington State University by XRF and ICP-MS (protocols in Johnson 177 et al., 1999) and are reported in Table S1A in the Supplementary Materials. Curacao 178 picrite samples were processed and analyzed in the geochemistry laboratory at the 179 Department of Geosciences at Virginia Tech following the procedures described in 180 Mazza et al. (2014). Major elements were collected by X-ray fluorescence (XRF), the 181 Relative Standard Deviation (RSD) for 10 replicates of BHVO-2g was $<2.70 \%$ for all 182 major elements and accuracy better than $1.74 \%$, with the excpetion of $\mathrm{P}_{2} \mathrm{O}_{5}$. Trace 183 elements as well as $\mathrm{P}_{2} \mathrm{O}_{5}$ were collected from the same fluxed glasses with an Agilent 184 7500ce ICPMS coupled with a Geolas laser ablation system, following the 
185 procedures detailed in Mazza et al. (2014). Data were calibrated against USGS 186 standards BCR-2, BHVO-2, G-2, and BIR-1a, using Ti from XRF as an internal

187 standard and the standard element values reported in Kelley et al. (2003). The 188 accuracy for 4 replicates of BHVO-2g was better than $5 \%$ for all elements except for $189 \mathrm{Ba}, \mathrm{Hf}$, and Ge (7-9 \%). The accuracy for 4 replicates of BIR-1a was better than $5 \%$ 190 for most elements except for Ga, Ge, Ce, Pr, Eu, Tb, Dy, Ho, Tm, Er, Yb, and Lu (5-9 $191 \%)$.

192 Acid-digested aliquots of the same powdered material was used to collect

193 radiogenic isotope ratios of $\mathrm{Pb}, \mathrm{Nd}$, and $\mathrm{Sr}$ on a Neptune multi collector ICPMS at the 194 Center for Elemental Mass Spectrometry (CEMS), University of South Carolina 195 (USC). Pb isotope ratios were determined by the Tl-addition technique (White et al., 1962000 ) using ${ }^{203} \mathrm{Tl} /{ }^{205} \mathrm{Tl}=0.418922$ and assuming identical fractionation factors 197 between $\mathrm{Tl}$ and $\mathrm{Pb}$. The $\mathrm{Pb} / \mathrm{Tl}$ ratio $\left({ }^{208} \mathrm{~Pb} /{ }^{205} \mathrm{Tl} \sim 7\right)$ of the samples was kept near 198 identical to the NBS 981 standard by first performing dip checks in the samples and 199 spiking Tl to the appropriate level. The NBS-981 standard was determined at $200{ }^{206} \mathrm{~Pb} /{ }^{204} \mathrm{~Pb}=16.936 \pm 0.001,{ }^{207} \mathrm{~Pb} /{ }^{204} \mathrm{~Pb}=15.490 \pm 0.001,{ }^{208} \mathrm{~Pb} /{ }^{204} \mathrm{~Pb}=36.694 \pm$ 2010.003 (2 standard deviations, = 13). Isotopic ratios for $\mathrm{Nd}$ were normalized to $202{ }^{146} \mathrm{Nd} /{ }^{144} \mathrm{Nd}=0.7219$ and the $\mathrm{Nd}$ standard $\mathrm{JNd}_{\mathrm{i}}$ was measured at ${ }^{143} \mathrm{Nd} /{ }^{144} \mathrm{Nd}=$ 2030.5121 and $0.512112 \pm 0.000007(\mathrm{n}=6)$ at USC. Isotopic ratios for $\mathrm{Sr}$ were 204 normalized to ${ }^{86} \mathrm{Sr} /{ }^{88} \mathrm{Sr}=0.1194$ and replicate analyses of ${ }^{87} \mathrm{Sr} /{ }^{86} \mathrm{Sr}$ at $0.710320 \pm$ 205 0.000012. All Sr measurements are reported relative to NBS-987 where ${ }^{87} \mathrm{Sr} /{ }^{86} \mathrm{Sr}=$ $206 \quad 0.710250$. 
208 corrected to initial eruptive values at $65 \mathrm{Ma}$ using parent/daughter values reported

209 in Table S1A. Additionally, we calculated the radiogenic composition of the Quepos

210 and CLIP sources at $65 \mathrm{Ma}$ and 90 Ma respectively by inverting primary magma

211 compositions of Quepos and CLIP lavas assuming a modal composition of a

212 refertilized peridotite and a melt fraction of $10 \%$. We then projected these values to

2130 Ma (assuming a radiogenic ingrowth corresponding to the source

214 parent/daughter ratios). This method allows for proper comparison of Quepos and

215 CLIP lavas to the present day isotopic domains in the Galápagos archipelago. We

216 tested the sensitivity of radiogenic source compositions to the degree of partial

217 melting and found negligible changes 10, 20, and 30\%. Inverted source

218 compositions for Quepos and CLIP samples, as well as additional details are

219 included in Table S1D.

220 We performed high-precision trace element analyses on Quepos olivines

221 using Rutgers University's JEOL JXA-8200 Superprobe. A modified version of the

222 Sobolev et al. (2007) protocol was used to obtain high precision trace-element data.

223 Samples were analyzed with a focused beam $(\sim 1$ ? $)$ at $20 \mathrm{kV}$ and $300 \mathrm{nA}$. Peak

224 count times were as follows: $\mathrm{Si}:$ 50s; $\mathrm{Mg}$ : 80s; Fe : 100s; Ni : 150s; Ca : 150s and Mn

225 : 150s. The San Carlos olivine standard was analyzed at regular intervals during

226 each run in order to correct for instrumental drift. A summary of the primary

227 standards, statistics for the secondary standards, and statistics for the olivine

228 analyses are given in Table S1B in Supplementary Materials. All oxide totals from

229 the olivine analyses were normalized to $100 \%$. Olivine data are also reported from 
230 Curacao lavas (Kerr et al., 1996b for sample 92-8 and Revillon et al., 1999 for sample 231 94-54).

\section{4. Petrological Modeling}

234 Our goal is to use high precision olivine data to infer the lithology of the 235 source that melted to produce the Quepos picrites; additionally, we examine olivines

236 from the older CLIP lavas from Curacao in order to provide constraints on how the 237 source lithology changed from $\sim 90$ to $70 \mathrm{Ma}$. A detailed description of the method 238 that was adopted for petrological modeling was provided previously (Herzberg, 239 2011; Herzberg et al., 2013; 2014), and is given again in the Supplementary

240 Materials. The model has the following components: 1) identification of a primary 241 magma composition, 2) calculation of a liquid line of descent after variable 242 proportions of olivine, clinopyroxene, and plagioclase have been subtracted, 3) 243 calculation of the compositions of olivine that crystallize from these derivative 244 magmas, 4) comparison of model and observed olivine compositions. The modeling 245 requires use of the olivine/melt distribution coefficients $\mathrm{D}$; for $\mathrm{Ni}$ we have chosen 246 the Beattie-Jones model (Jones, 1984; Beattie et al., 1991); for Ca and Mn we use the 247 models in Herzberg and O'Hara (2004) and for Fe-Mg exchange between olivine and 248 melt we use the model of Toplis (2005). There are other olivine/liquid distribution 249 models for $\mathrm{Ni}$, and all are parameterizations of experimental data. Of these, the 250 Beattie-Jones model has the minimum root mean square error (RMSE) (reproducing 251 experimentally collected data (Herzberg et al., 2013; 2014). 
253 melt decreases as temperature increases, and the inference is that deep melting of

254 peridotite will produce $\mathrm{Ni}$ rich melts that crystallize Ni-rich olivine near the surface.

255 They proposed that the $\mathrm{NiO}$ contents of olivines greater than $0.37 \%$ in mantle

256 peridotites are proportional to the difference in temperature between melting in the

257 mantle and crystallization near the surface, i.e., the $\Delta \mathrm{T}$ effect. The difficulties with

258 this model were previously examined (Herzberg et al., 2013; 2014) and we will

259 draw attention to several points that compromise its use for interpreting the

260 Curacao and Quepos olivine phenocrysts. The Beattie-Jones Ni partitioning model is

261 more accurate than the Matzen et al. (2013) in describing the experimental data

262 (Herzberg et al., 2013; 2014). The 1 RMSE for the Beattie-Jones model is 1.1; the 1

263 RMSE for the Matzen model is 2.5 (Herzberg et al., 2014). Therefore, the difference

264 in olivine $\mathrm{NiO}$ between average Hawaii and spinel peridotite (i.e., $0.46 \%$ and $0.37 \%$ )

265 discussed by Matzen et al. (2013) is fully accounted for by the 1 RMSE of 2.5. Thus,

266 the $\Delta \mathrm{T}$ interpretation for the high $\mathrm{NiO}$ in Hawaiian olivines is undermined by the

267 uncertainty. In the Beattie-Jones model the effect of $\mathrm{T}$ on $\mathrm{D}_{\mathrm{Ni}}$ is accounted for in the

$268 \mathrm{MgO}$ content of the melt, but in the Matzen et al. (2013) model, the separation of T

269 and melt $\mathrm{MgO}$ as independent variables likely accounts for the larger RMSE. As

270 discussed below, olivine compositions from Curacao crystallized from hot

271 peridotite-source primary magmas, yet they display no elevations in $\mathrm{Ni}$.

272 Additionally, the highest olivine Ni contents worldwide are found in subduction

273 zone lavas from the Mexican Volcanic Belt (Straub et al., 2008), yet there is no

274 thermal anomaly below this region. Finally, we reiterate that the inference of a 
275 pyroxenite or refertilized peridotite source from elevated Ni using the Beattie-Jones

276 model is internally consistent with $\mathrm{Ca}$ and $\mathrm{Fe} / \mathrm{Mn}$, but no such consistency was

277 provided in the Matzen et al. (2013) model.

279 5. RESULTS

280

The matrix of three samples from Quepos (two basalts and one picrite) were

281 dated by ${ }^{40} \mathrm{Ar} /{ }^{39} \mathrm{Ar}$, and yielded weighted mean plateau ages of $61.4 \pm 0.6,68.6 \pm 0.3$,

$28270.6 \pm 1.2 \mathrm{Ma}$. Supporting data summarizing the ${ }^{40} \mathrm{Ar} /{ }^{39} \mathrm{Ar}$ age dating results are

283 located in the Supplementary Materials (Tables 2A-E). Previously published

$284{ }^{40} \mathrm{Ar} /{ }^{39} \mathrm{Ar}$ ages of Quepos basalts yielded ages at 60-65 Ma (Sinton et al., 1997;

285 Hoernle et al., 2002). Our new measurements agree with the $\sim 60$ Ma pulse and

286 extend the maximum age of Quepos volcanism to $70 \mathrm{Ma}$, indicating that the

287 formation of this complex may have occurred over a 10 Ma interval.

$288 \quad$ New major and trace element results are plotted in Figures 2 and 3. Quepos

289 lavas belong to both alkaline and sub-alkaline series (Fig. 2A). These lavas are

290 mostly classified as basalts, with some examples of basaltic andesites, trachybasalts,

291 and one basanite (Fig. 2A). Quepos picrites fall within the picro-basalt/basalt

292 compositional fields (Fig. 2A) but textural and petrological evidence

293 (Supplementary Materials, Section S1) suggest that they are not liquids but

294 cumulates produced by olivine accumulation. Nevertheless, their olivine-controlled

295 high $\mathrm{MgO}$ (>10 wt\%) compositions and abundance of fresh olivines make them ideal

296 for source composition determinations and petrological studies. Quepos picrites

297 plot below the peridotite-pyroxenite discrimination line (Fig. 2B) defined by 
298 Herzberg and Asimow (2008). In contrast, the older Curacao picrites (Kerr et al., 299 1996b, this study) plot on or above the line, in range with other CLIP samples 300 consistent with a peridotite source. Primitive mantle normalized spider-diagrams 301 from Quepos samples display broad enrichment in incompatible elements (Fig. 3).

302 These lavas show marked positive high-field strength element enrichments 303 (positive $\mathrm{Ta}, \mathrm{Nb}$, and Ti anomalies) as well as depletions in fluid mobile elements (K,

$304 \mathrm{Rb}, \mathrm{Th}, \mathrm{U})$ relative to elements with similar compatibilities. Additionally, the trace 305 element abundances of our samples closely resemble the incompatible element 306 patterns of current Galápagos hotspot tracks; the Cocos, Coiba, and Carnegie ridges 307 (Fig. 3).

308 High precision data on olivine interpreted as derived from a mantle 309 peridotite source from a wide range of tectonic environments contain a range of 310 2800-3100 ppm Ni (Herzberg et al., 2013). These contents are consistent with 311 values from olivine in primitive MORB from the East Pacific Rise and olivines 312 inferred to have crystallized from primary magmas of Archean komatiites 313 (Herzberg, 2011a; Herzberg et al., 2013). CLIP olivines from the $\sim 90$ Ma lavas of 314 Curacao are another example of peridotite-source olivines (Fig. 4). Olivine 315 compositions trend towards $3000 \mathrm{ppm} \mathrm{Ni}$ and $2000 \mathrm{ppm} \mathrm{Ca}$, consistent with 316 magmas derived from a peridotite source. Importantly, these olivines crystallized 317 from hot primary magmas $\left(\mathrm{T}_{\mathrm{p}}=1540^{\circ} \mathrm{C} ; \mathrm{MgO}=18 \%\right.$; Herzberg and Gazel, 2009;

318 Hastie and Kerr, 2010), yet there is no evidence for elevated Ni in Curacao olivines 319 that would support the $\Delta \mathrm{T}$ model (Matzen et al., 2013). Curacao olivines have low 320 Ni contents (Fig. 4), unlike high Ni Hawaiian olivines (Fig. 5). 
When olivine Mg numbers are greater than 90, pyroxenite or refertilzed

322 peridotite formed by reaction of partial melts of recycled crust with peridotite are

323 often revealed in olivine phenocrysts with high $\mathrm{Ni}$, low $\mathrm{Ca}$, low $\mathrm{Mn}$ and high $\mathrm{Fe} / \mathrm{Mn}$

324 compared to olivines that crystallize from melts of normal MORB-like peridotite

325 (Sobolev et al., 2005; 2007; Gurenko et al., 2009; 2010; Herzberg, 2011; Herzberg et

326 al., 2014). Olivines from Quepos (Fig. 5) are too high in Ni and Fe/Mn and too low in

327 Ca to have crystallized from normal mantle peridotite such as the source of MORB,

328 Archean komatiites, and Curacao lavas (Fig. 4). They are also similar to olivines from

329 Mauna Kea for which a pyroxenite source has been inferred (Sobolev et al., 2007;

330 Herzberg, 2011a).

331 Seven new sets of $\mathrm{Sr}-\mathrm{Nd}-\mathrm{Pb}$ isotope ratios are provided in this study (Table

332 S1A and Fig. 6). These ratios were first age corrected using an average age of $65 \mathrm{Ma}$

333 and then used to project the radiogenic ingrowth of the source, as described in the

334 methods above. These values are plotted in Figure 6 along with modern Galápagos

335 Plume isotopic domains (Hoernle et al. 2000; Harpp and White, 2001) and

336 previously published CLIP and Nicoya data, also projected to present day (Hauff et

337 al., 2000a, 2000b; Hoernle et al., 2004). A detailed description and discussion of the

338 isotope age corrections and source projections can be found in Supplementary

339 Materials.

341 6. DISCUSSION

342 The new ${ }^{40} \mathrm{Ar} /{ }^{39} \mathrm{Ar}$ ages presented in this study, suggest that Quepos

343 volcanism lasted for approximately $10 \mathrm{Ma}$ beginning at $\sim 70 \mathrm{Ma}$ and terminating at 
$344 \sim 60$ Ma. Our new data suggest that the initial melting event, which formed this

345 terrane occurred $\sim 5$ Ma earlier than previously described (Hoernle et al., 2002). The

346 trace-element patterns reveal similarities with the current Galápagos hotspot

347 tracks; the Cocos, Coiba, and Carnegie Ridges (Fig. 3). Therefore, the Quepos terrane

348 is possibly the oldest accreted Galápagos OIB terrane found in Central America and

349 records the transitional phase between LIP and OIB-type volcanism.

350 CaO-MgO bulk rock compositions can be used as a first order discrimination

351 between peridotite and pyroxenite source-derived melts (Herzberg and Asimow,

352 2008). Samples from the CLIP plot in the area consistent with a dominantly

353 peridotitic source composition (Fig. 2B), although it is also possible that some

354 pyroxenite lithologies can also produce high CaO magmas (Herzberg, 2011). Our

355 new samples from Quepos plot below that line and are similar to the range exhibited

356 by Mauna Kea (Hawaii) lavas, which have been interpreted to be derived from a

357 pyroxenite source (Sobolev et al., 2007; Herzberg, 2011a). We note that no

358 experimental melt compositions of peridotites have been reported that plot below

359 the discrimination line, supporting evidence that low CaO primary magmas

360 originated by pyroxenite melting. Modern Galápagos archipelago lavas plot above

361 and below the discrimination line, consistent with the presence of both peridotite

362 and pyroxenite sources in the plume (Vidito et al. 2013). Also, one lava composition

363 from Quepos reported by Tournon (1984) plots above the line, and this was used to

364 model the olivines for peridotite source melts (Fig. 5).

365 New high-precision data from Quepos olivine phenocrysts show that they

366 have higher $\mathrm{Ni}$ and Fe/Mn and lower Ca contents than those expected of a normal 
367 peridotite source (Fig. 5). While Quepos and Mauna Kea olivines share many

368 similarities (Fig. 5), there are also differences that may be interpreted as variable

369 amounts of olivine in the source, which may be present in Quepos and variably

370 present or even absent in Mauna Kea (Sobolev et al., 2005; Herzberg, 2011a).

371 The observed trends in $\mathrm{Ni}$ and $\mathrm{Ca}$ in Quepos olivines suggest that sole 372 crystallization of olivine is not sufficient to explain the data. Quepos olivines are too

373 low in Ca and too high in Ni to be derived from a pure pyroxenite end member (Fig.

374 5). The best fit occurs when olivine and clinopyroxene crystallize along a cotectic.

375 However, this is problematic for several reasons. First, Quepos picrites lack

376 clinopyroxene. Although magmas can crystallize olivine + clinopyroxene at high-

377 pressures and then only olivine within shallower crustal magma chambers (e.g.

378 Thompson et al., 1980; O’Donnell and Presnall, 1980; Elthon et al., 1995), this

379 process would be preserved in the geochemical signature of these picrites. The lack

380 of decreasing $\mathrm{Sc} / \mathrm{Al}$ and $\mathrm{Ca} / \mathrm{Al}$ with decreasing $\mathrm{MgO}$ does not support polybaric

381 crystallization for Quepos samples. However, fractional crystallization coupled with

382 magma recharge and mixing from a pyroxenite source provides a viable explanation

383 to the Ni and Ca trends observed in Quepos olivines (Fig. 5). The recharge model

384 shows that Quepos olivines crystallized from mixtures between the pyroxenite-

385 derived primary magma and a derivative liquids with Mg\# of 75 to 84 (Fig. 5). It is

386 important to note that $\mathrm{Ni}$ and $\mathrm{Ca}$ are elements sensitive to magma recharge and

387 mixing while $\mathrm{Fe} / \mathrm{Mn}$ remains insensitive to this process. A detailed discussion of 388 magma chamber recharge and mixing model is provided in the Supplementary 389 Materials section. 
Source-projected isotope variations in ${ }^{143} \mathrm{Nd} /{ }^{144} \mathrm{Nd}$ and ${ }^{208} \mathrm{~Pb} /{ }^{204} \mathrm{~Pb}$ and $391{ }^{206} \mathrm{~Pb} /{ }^{204} \mathrm{~Pb}$ reveal that the Quepos terrane is most similar to the Central Domain of

392 the Galápagos archipelago (Fig. 6). Nicoya and Curacao basalts also show similarity 393 to the Central Domain, although are typically less radiogenic in $\mathrm{Pb}$ isotopic

394 composition and more radiogenic in Nd isotopic composition than Quepos lavas. In 395 the modern archipelago the Central Domain is by far the most widespread and 396 defines lavas from Fernandina and Isabella (Harpp and White, 2001). This 397 component dominates the center of the archipelago, whereas the other components 398 prevail in the peripheral areas (Harpp and White, 2001). The trace element 399 chemistry, radiogenic isotope ratios, and ${ }^{3} \mathrm{He} /{ }^{4} \mathrm{He}$ ratios (Graham et al., 1993; Kurz 400 and Geist, 1999) of Fernandina all suggest that lavas erupted in the western reaches 401 of the archipelago represent the most undegassed, primitive part of the Galápagos 402 plume (Harpp and White, 2001).

403 Previous studies suggested some possible mechanisms leading to the 404 formation of isotopically distinct domains in the Galápagos plume source include: 1) 405 recycling and entrainment of ancient oceanic crust into the plume (Hart, 1984), 2) 406 recycling of subducted sediment (Dupré and Allégre, 1983), 3) delamination of 407 subcontinental lithosphere (Hart, 1984). Based on the new data presented here, we 408 favor the interpretation that recycled oceanic crust is responsible for the more 409 radiogenic $\mathrm{Pb}$ isotopic nature of the Quepos terrane, relative to CLIP lavas.

410 Our new ${ }^{40} \mathrm{Ar} /{ }^{39} \mathrm{Ar}$ ages and geochemical data provide valuable insight into a 411 crucial phase during the life cycle of the Galápagos plume during the LIP-OIB stage 412 transition, thereby elucidating the "head-tail plume evolution". A fundamental 
413 question that remains is: what effect does recycled oceanic crust in the form of

414 pyroxenite contribution have on the evolutionary history of the Galápagos plume?

415 Herzberg and Gazel (2009) proposed that CLIP lavas melted hotter and more

416 extensively than lavas from the 0-15 Ma archipelago and Carnegie and Cocos tracks

417 (Fig. 7A). A significant decrease in $\mathrm{T}_{\mathrm{p}}\left(\sim 75^{\circ} \mathrm{C}\right)$ is also observed between $\sim 90 \mathrm{Ma}$

418 CLIP lavas and 65 Ma Quepos lavas (Herzberg and Gazel, 2009). Interestingly,

419 there is also an increasing trend in high-field strength elements (HFSE), particularly

$420 \mathrm{Nb} / \mathrm{Nb}^{*}\left(\right.$ defined as $\mathrm{Nb}_{\mathrm{N}} / \sqrt{ }\left(\mathrm{Th}_{\mathrm{N}} \times \mathrm{La}_{\mathrm{N}}\right)$ ) from $\sim 90$ to $0 \mathrm{Ma}$ (Fig. 7B). HFSE's such as $\mathrm{Nb}$

421 are sequestered in refractory mineral phases, e.g., rutile, in a subducting slab, thus

422 the increase in $\mathrm{Nb} / \mathrm{Nb}^{*}$ between 90 and 65 Ma may reflect a significant increase in

423 recycled oceanic crust as the pyroxenite source for Quepos lavas. Jackson et al.,

424 (2008) presented evidence for a global enriched HFSE reservoir commonly sampled

425 by OIBs with correspondingly high ${ }^{3} \mathrm{He} /{ }^{4} \mathrm{He}$, and radiogenic ${ }^{187} \mathrm{Os} /{ }^{188} \mathrm{Os}$ that

426 collectively suggest the existence of a mantle source with a refractory eclogite

427 (pyroxenite) component (Jackson et al., 2008). This result advocates important

428 implications for the development of global mantle geochemical heterogeneity. The

429 high ${ }^{3} \mathrm{He} /{ }^{4} \mathrm{He}$ ratios of erupted lavas at some hotspots (Galápagos, Hawaii, Samoa,

430 Iceland) are interpreted to originate from a relatively primitive, undegassed mantle

431 reservoir (Kurz et al., 1982; Farley et al., 1992), named PHEM (Farley et al., 1992),

432 FOZO (Hart et al., 1992), or C (Hanan and Graham, 1996). Understanding the nature

433 of such a primitive, undegassed mantle reservoir and the development of a

434 nonprimitive (nonchondritic?) mantle component is therefore crucial for

435 understanding the formation of the high HFSE - high ${ }^{3} \mathrm{He} /{ }^{4} \mathrm{He}$ domain frequently 
436 sampled by some plumes (Galápagos, Iceland, Hawaii, Samoa), balancing Earth's

437 HFSE budget from subduction to deep recycling, and evaluating large-scale

438 planetary differentiation processes (Jackson et al., 2008).

439 Evidence is accumulating that the amount of recycled crust in the Galápagos

440 mantle plume has been increasing with time. Peridotite-source melting is consistent

441 with the $\sim 90$ Ma CLIP lavas that have high $\mathrm{CaO}$ contents (Fig. 2B) and olivine data

442 that indicate a peridotite source provenance (Fig. 4). The first evidence for

443 participation of a dominant recycled crust component is at $\sim 70 \mathrm{Ma}$ as documented

444 in this paper by lavas from the Quepos terrane. And in modern lavas, olivine

445 chemistry reveals the widespread occurrence of pyroxenite throughout the present-

446 day Galápagos archipelago (Vidito et al., 2013). However, determining secular

447 changes in the absolute amount of recycled crust contained in the Galápagos plume

448 is difficult because of its lower solidus and higher melt productivity relative to

449 peridotite (e.g., Morgan, 2001; Pertermann and Hirschmann, 2003; Ito and

450 Mahoney, 2005; Sobolev et al., 2007; Shorttle and Maclennan, 2011). That is, given

451 the same lithological mixture of peridotite and pyroxenite, if the plume is cooler for

452 any reason, pyroxenite will preferentially melt owing to its lower melting

453 temperature, and its elevated productivity will mean that pyroxenite-source melts

454 will be overly abundant. However, these petrological constraints provide a

455 qualitative framework for explaining the larger geodynamical framework for

456 cooling the plume with time (Fig. 7A).

457 Petrological modeling suggests that most LIPS (Paleocene and older) were

458 hotter and melted more extensively than younger ocean islands, maybe only with 
459 the exception of Hawaii (Herzberg and Gazel, 2009). It would be difficult to imagine 460 a scenario of LIPs-producing plumes rooted in a hotter boundary layer at the base of

461 the mantle than younger ocean island-producing plumes. If we assume that the

462 Galápagos is representative of global plume evolution, and that recycled crust

463 remains negatively buoyant relative to peridotite at all depths in the mantle (Hirose,

464 2006; Ricolleau et al., 2010), then it is possible that mantle plumes were triggered

465 near the core-mantle boundary by instabilities of the buoyantly-favored perovskite-

466 bearing peridotite equivalent, and that they progressively entrained more recycled

467 crust with time. According to Davaille et al. (2002) entrainment of dense crust

468 would require a hotter mantle to rise, which is not consistent with the Galápagos

469 plume. An alternative explanation is that relative to the recycled crust-free

470 peridotite equivalent, mantle plumes that entrain a limited amount of recycled crust

471 of limited volume are expected to have a longer transit ascent time, creating

472 opportunities for greater conductive heat loss to their surroundings (Farnetani and

473 Samuel, 2005; Nolet et al., 2006; Kumagai et al., 2008). The problem with this model

474 is that increased recycled crust entry into the root of the plume can be confused

475 with increased melt productivity of recycled crust that is expected from cooling.

476 Detailed work on the oldest 90 Ma CLIP lavas and additional Galápagos-related

477 terranes might break this interpretative circularity if it can constrain whether the

478 LIP source was free of recycled crust or if it was present, but completely exhausted 479 and diluted during partial melting.

480

481 7. CONCLUSIONS 
483 in the history of the Galápagos Plume occurred at about 70-60 Ma, i.e. 20-30 Ma

484 after the onset of CLIP volcanism. Our results show that a dominant pyroxenite 485 source lithology is observed for the first time at $\sim 70 \mathrm{Ma}$ in the record of the Quepos 486 terrane.

487 The maximum $\mathrm{T}_{\mathrm{p}}$ of the plume changed from $\sim 1650$ to $\sim 1550{ }^{\circ} \mathrm{C}$ between

488 90-70 Ma. This change corresponds to a dominant pyroxenite component in the 489 Galápagos plume evident in the Quepos data. Furthermore, there is also an increase 490 in HFSE contents relative to equally incompatible elements throughout the 491 evolution of the plume. The petrological requirement of elevated melt productivity 492 of pyroxenite relative to peridotite in a cooling lithologically heterogeneous mantle 493 is well-illustrated by the Galápagos plume. However, with no obvious reason for 494 plume material being cooler at the time of tail versus plume head formation, we 495 consider an increased incorporation of pyroxenite into the plume tail as the cause 496 for the secular cooling of the plume tail relative to the head most likely. This secular 497 cooling would be caused due to the decreased buoyancy of the plume material with 498 a higher pyroxenite proportion resulting in a slower ascent rate through the mantle 499 and thus, a higher cooling rate. The increased pyroxenite contribution through time 500 would in this case reflect the effect of an increased proportion in the plume tail 501 combined with an increased melt production rate.

$502 \quad \mathrm{Sr}-\mathrm{Nd}-\mathrm{Pb}$ radiogenic isotopic compositions suggest that the source of the $\sim 65$

503 Ma Quepos terrane contains intermediate signatures similar to the classically 504 defined Central Domain and are more radiogenic than CLIP lavas, suggesting an 
505 enrichment in the source of the plume, probably the result of a recycled oceanic

506 crust component.

507

508 ACKNOWLEDGEMENTS

509

510 The National Science Foundation Award EAR- 12019033, Evolution of the Galápagos

511 Mantle Plume to Gazel and Class supported this project. Reviews and comments by N.

512 Sou and S. Mazza improved the original manuscript. Thanks go to Andrew Kerr for

513 providing samples from Curacao and Anne Davaille for comments. This is Lamont-

514 Doherty Earth Observatory (LDEO) Contribution \# (number provided when the

515 manuscript is accepted for publication). The authors are very grateful to Catherine

516 Chauvel and an anonymous reviewer for thoughtful and critical comments that

517 greatly improved this paper.

518

519

520 REFERENCES

521 Allan, J.F., Simkin, T., 2000. Fernandina Volcano's evolved, well-mixed basalts:

522 Mineralogical and petrological constraints on the nature of the Galápagos

523 plume. J. Geophys. Res. 105, 6041-6071.

524 Alvarado, G. E., Denyer, P., Sinton, C. W., 1997. The 89 Ma Tortugal komatiitic

525 suite, Costa Rica: Implications for a common geological origin of the

526 Caribbean and Eastern Pacific region from a mantle plume. Geology, 25 (5),

$527 \quad 439-442$. 
528 Arndt, N., 2000. Hot heads and cold tails. Nature, 407, 458-461.

529 Ballmer, M.D., Ito, G., Wolfe, C.J., Solomon, S.C., 2013. Double layering of a

530 thermochemical plume in the upper mantle beneath Hawaii. Earth Planet. Sci.

$531 \quad$ Lett. 376, 155-164.

532 Blackburn, T.J., Olsen, P.E., Bowring, S.A., McLean, N.M., Kent, D.V., Puffer, J., McHone,

533 G., Rasbury, E.T., Et-Touhami, M., 2013. Zircon U-Pb geochronology links the

534 end-Triassic extinction with the Central Atlantic Magmatic Province. Science, $535 \quad 340,941-945$.

536 Blichert-Toft, J., White., W. M., 2001. Hf isotope geochemistry of the Galápagos

537 Islands. Geochem. Geophys. Geosyst. 2, http://dx.doi.org2000GC000138.

538 Burke, K., 2011. Plate Tectonics, the Wilson Cycle, and Mantle Plumes: Geodynamics 539 from the Top. Ann. Rev. Earth Planet. Sci. 39 (1), 1-29.

540 Beattie, P., Ford, C., Russell, D., 1991. Partition coefficients for olivine-melt and

541 orthopyroxene-melt systems. Cont. Mineral. Petrol. 109, 212-224.

542 Danyushevsky, L. V., and Plechov, P., 2011. Petrolog3: Integrated software for 543 modeling crystallization processes. Geochem. Geophys. Geosyst. 12 (7). $544 \quad$ http//dx.doi.org/10.1029/2011GC003516.

545 Chauvel, C., Lewin, E., Carpentier, M., Arndt, N. T., Marini, J.-C., 2008. Role of

546 recycled oceanic basalt and sediment in generating the Hf-Nd mantle array. $547 \quad$ Nat. Geo. 1 (1), 64-67.

548 Coffin, M. F., Duncan, R. A., Eldholm, O., Fitton, J. G., Frey, F. A., Larsen, H. C., Mahoney, 549 J. J., Saunders, A. D., Schlich, R., Wallace, P. J., 2006. Large Igneous Provinces 550 and Scientific Ocean Drilling status quo and a look ahead. Oceanography. 19, 
$150-160$.

552 Coffin, M. F., Eldholm, O., 1994, Large igneous provinces: crustal structure,

553 dimensions, and external consequences. Rev. Geophys, 32, 1-36.

554 Courtillot, V.E., Renne, P.R., 2003. On the ages of flood basalt events. Comptes

$555 \quad$ Rendus Geoscience. 335, 113-140.

556 Denyer, P., Gazel, E., 2009. The Costa Rican Jurassic to Miocene oceanic

557 complexes: Origin, tectonics and relations. J. South Am. Earth Sci. 28 (4), 429-

$558 \quad 442$.

559 Duncan, R., Hargraves, R., 1984. Plate tectonic evolution of the Caribbean region

560 in the mantle reference frame. Geol. Soc. Am. Mem. 162, 81-94.

561 Dupré, B., and Allegre, C. J., 1983. Pb-Sr isotope variation in Indian Ocean basalts

562 and mixing phenomena. Nature. 303, 142-146.

563 Duran, P., 2013. Estudio vulcano-estructural y sedimentario del mélange en el

564 Promontorio de Quepos, Pacífico Central, Costa Rica. University of Costa Rica.

565 Central American School of Geology. Masters Thesis.

566 Elthon, D.,Ross, D.K.,Meen, J.K., 1995. Compositional Variations of Basaltic Glasses

567 from the Mid-Cayman Rise Spreading Center. J. Geophys. Res. 100 (B7), $568 \quad 12497-12512$.

569 Farley, K. A., Craig, H., 1992. Mantle Plumes and Mantle Sources. Science, 258

570 (5083), 821-822.

571 Farnetani, C. G., Samuel, H., 2005. Beyond the thermal plume paradigm:

572 Geophys. Res. Lett. 32, 1-4.

573 Frisch, W., Meschede, M., Sick, M., 1992. Origin of the Central American 
ophiolites: Evidence from paleomagnetic results. Geol. Soc. Am. Bull. 104

575

576

577

578

579

580

581

582

583

584

585

586

587

588

589

590

591

592

593

594

595

596 (10), 1301-1314.

Gale, A., Dalton, C.A., Langmuir, C.H., Su, Y., Schilling, J.-G., 2013. The mean composition of ocean ridge basalts. Geochem. Geophys. Geosyst. 14, 489-518. http://dx. doi:10.1029/2012GC004334

Gazel, E., Abbott R. N, Draper, G. 2011., Garnet-bearing ultramafic rocks from the Dominican Republic: Fossil mantle plume fragments in an ultra high pressure ceanic complex? Lithos. 125 (1-2), 393-404.

Geist, D., White, W.M., Albarede, F., Harpp, K., Reynolds, R., Blichert-Toft, J., Kurz, M.D., 2002. Volcanic evolution in the Galápagos: The dissected shield of Volcan Ecuador. Geochem. Geophys. Geosyst. 3 (1). http://dx. doi:10.1029/2002GC000355 of 32-32 of 32.

Geldmacher, J., Hanan, B. B., Blichert-Toft, J., Harpp, K., Hoernle, K., Hauff, F., Werner, R., Kerr, A. C., 2003. Hafnium isotopic variations in volcanic rocks from the Caribbean Large Igneous Province and Galápagos hot spot tracks. Geochem.Geophys.Geosyst. 4 (7). http://dx.doi.org/10.1029/2002GC000477

Graham, D. W., Christie, D. M., Harpp, K. S., Lupton, J. E., 1993. Mantle Plume Helium in Submarine Basalts from the Galápagos Platform. Science. 262, 2023-2026.

Hanan, B. B., Graham, D. W., 1996. Lead and helium isotope evidence from oceanic basalts for a common deep source of mantle plumes. Science. 272 (5264), 991-995.

Harpp, K. S., White, W. M., 2001. Tracing a mantle plume: Isotopic and trace 
element variations of Galápagos seamounts. Geochem. Geophys. Geosyst. 2, http://dx.doi.org/2000GC000137.

599 Hart, S., Hauri, E., Oschmann, L., Whitehead, J., 1992. Mantle plumes and

600 entrainment: isotopic evidence. Science. 256, (5056) 517-520.

601 Hart, S. R., 1984. A large-scale isotope anomaly in the Southern Hemisphere mantle.

602 Nature. 309, 753-757.

603 Hastie, A.R., Kerr, A.C., 2010. Mantle plume or slab window?: physical and 604 geochemical constraints on the origin of the Caribbean oceanic plateau. Earth Sci. Rev., 98, 283-293.

606 Hauff, F., Hoernle, K., Schmincke, H.U., Werner, R., 1997. A Mid Cretaceous

607 origin for the Galápagos hotspot: volcanological, petrological, and 608 geochemical evidence from Costa Rican oceanic crustal segments. Geol. Rund. $609 \quad 86,141-155$

610 Hauff, F., Hoernle, K., Tilton, G., Graham, D. W., Kerr, A. C., 2000a. Large volume recycling of oceanic lithosphere over short time scales: geochemical constraints from the Caribbean Large Igneous Province. Earth Planet Sci.

614 Hauff, F., Hoernle, K., van den Bogaard, P., Alvarado, G., Garbe-Schönberg, D.,

615 2000b. Age and geochemistry of basaltic complexes in western Costa Rica:

616 Contributions to the geotectonic evolution of Central America. Geochem. 617 Geophys. Geosyst. 1 (5). http://dx.doi.org/10.1029/1999GC000020.

618 Herzberg, C., 2011a. Identification of Source Lithology in the Hawaiian and Canary 619 Islands: Implications for Origins. J. Petrol. 52, 113-146. 
620 Herzberg, C., Asimow, P. D., 2008. Petrology of some oceanic island basalts: PRIMELT2.XLS software for primary magma calculation. Geochem. Geophys. Geosyst. 9 (9). http://dx.doi.org/10.1029/2008GC002057

623 Herzberg, C., Asimow, P.D., Ionov, D.A., Vidito, C., Jackson, M.G., Geist, D., 2013. Nickel 624 and helium evidence for melt above the core-mantle boundary. Nature 493, 625 393-397.

626 Herzberg, C., Cabral, R.A., Jackson, M.D., Vidito, C., Day, J.M.D., Hauri, E., 2014. 627 Phantom Archean crust in Mangaia hotspot lavas and the meaning of 628 heterogeneous mantle. Earth Planet. Sci. Lett. 396, 97-106.

629 Herzberg, C., Gazel, E., 2009. Petrological evidence for secular cooling in mantle $630 \quad$ Plumes. Nature. 458, 619-623.

631 Herzberg, C., O’Hara, M.J., 2002. Plume-associated ultramafic magmas of $632 \quad$ Phanerozoic age. J. Petrol. 43, 1857-1883.

633 Hirose, K., 2006. Postperovskite phase transition and its geophysical implications. 634 Rev. Geophys. 44, 2005RG000186, RG3001.

635 Hoernle, K., Hauff, F., van den Bogaard, P, 2004, 70 m.y. history (139-69 Ma) for the 636 Caribbean large igneous province. Geology. 32 (8), 697-700.

637 Hoernle, K., Werner, R., Phipps Morgan, J., Garbe-Schönberg, C.D., Bryce, J.G., Mrazek, 638 J., 2000. Existence of complex spatial zonation in the Galápagos plume for at 639 least 14 m.y. Geology. 28, 435-438.

640 Hoernle, K., van den Bogaard, P., Werner, R., Lissinna, B., Hauff, F., Alvarado, G., 641 Garbe-Schönberg, D., 2002. Missing history (16-71 Ma) of the Galápagos 642 hotspot: Implications for the tectonic and biological evolution of the 

Americas. Geology. 30 (9), 795-798.

644 Hofmann, A. W., 1997. Mantle geochemistry: the message from oceanic volcanism. $645 \quad$ Nature. 385, 219-229.

646 Ito, G., Mahoney, J.J., 2005. Flow and melting of a heterogeneous mantle: 1. Method 647 and importance to the geochemistry of ocean island and mid-ocean ridge 648 basalts. Earth. Planet. Sci. Lett., 230, 29-46.

649 Jackson, M.G., Dasgupta, R., 2008. Compositions of HIMU, EM1, and EM2 from global 650 trends between radiogenic isotopes and major elements in ocean island 651 basalts. Earth. Planet. Sci. Lett., 276, 175-186.

652 Jackson, M. G., Hart, S. R., Saal, A. E., Shimizu, N., Kurz, M. D., Blusztajn, J. S.,

653 Skovgaard, A. C., 2008. Globally elevated titanium, tantalum, and niobium 654 (TITAN) in ocean island basalts with high ${ }^{3} \mathrm{He} /{ }^{4} \mathrm{He}$. Geochem. Geophys. 655 Geosyst. 9. http://dx.doi.org/10.1029/2007GC001876.

656 Jackson, M.G., Weis, D., Huang, S., 2012. Major element variations in Hawaiian shield 657 lavas: Source features and perspectives from global ocean island basalt (OIB) 658 systematics.

Geochem.

Geophys.

Geosyst.

13. http://dx.doi:10.1029/2012GC004268

660 Jicha, B. R., Brown, F. H., 2014. An age on the Korath Range and the viability of $661{ }^{40} \mathrm{Ar} /{ }^{39} \mathrm{Ar}$ dating of kaersutite in Late Pleistocene volcanics, Ethiopia, Quat. $662 \quad$ Geochron. 21, 53-57.

663 Johnson, D. M., Hooper, P. R., Conrey, R. M., 1999. XRF Analysis of rocks and 664 minerals for major and trace elements on a single low dilution Li-tetraborate 665 fused bead. Advances in X-ray Anal. 41, 843-867. 
666 Kamber, B., Collerson, K., 2000. Zr/Nb systematics of ocean island basalts reassessed-the case for binary mixing. J. Petrol. 41 (7), 1007-1021.

668 Kerr, A. C., 2005. Oceanic LIPs: The Kiss of Death: Elements. 1, 289-292.

669 Kerr, A. C., Marriner, G. F., Arndt, N., Tarney, J., Nivia, A., Saunders, A. D., Duncan,

670 R. A., 1996a. The petrogenesis of Gorgona komatiites, picrites and basalts:

671 new field, petrographic and geochemical constraints. Lithos. 37, 245-260.

672 Kerr, A. C., Tarney, J., Marriner, G. F., Klaver, G. T., Saunders, A. D., Thirlwall, M. and basalts of Curaçao, Netherlands Antilles: a remnant of an oceanic plateau: Cont. Mineral. Petrol. 124 (1), 29-43.

676 Kuiper, K.F., Deino, A., Hilgen, F.J., Krijgsman, W., Renne, P.R., Wijbrans, J.R., 2008. Synochronizing Rock Clocks of Earth History. Science 320, 500-504.

678 Kumagai, I., Davaille, A., Kurita, K., Stutzmann, E., 2008. Mantle plumes: Thin, fat, successful, or failing? Constraints to explain hot spot volcanism through time and space. Geophys.

Res.

Lett. 35 http://dx.doi.org/10.1029/2008GL035079

682 Kurz, M. D., Jenkins, W. J., Hart, S. R., 1982. Helium isotopic systematics of oceanic 683 islands and mantle heterogeneity. Nature. 297, 43-47.

684 Kurz, M. D., Geist, D., 1999. Dynamics of the Galápagos hotspot from helium isotope 685 geochemistry. Geochim. Cosmochim Acta. 63 (23/24), 4139-4156.

686 Kurz, M. D., Rowland, S. K., Curtice, J., Saal, A. E., Naumann, T., 2014. Eruption Rates 687 for Fernandina Volcano, The Galápagos. In Harpp, K.S., Mittelstaedt, E., d'Ozouville, N., Graham, D.W. (Eds.), A New Chronology at the Galápagos 
Hotspot Center. John Wiley \& Sons Inc., Chapter 4, pp. 41-54.

$690 \mathrm{Li}, \mathrm{C} .$, Ripley, E.M, 2010. The relative effects of composition and temperature on 691 olivine-liquid Ni partitioning: Statistical deconvolution and implications for petrologic modeling. Chem. Geol. 275, 99-104.

693 Loewen, M. W., Duncan, R. A., Kent, A. J. R., Krawl, K., 2013. Prolonged plume 694 volcanism in the Caribbean Large Igneous Province: New insights from 695 Curaçao and Haiti. Geochem. Geophys. Geosyst. 14 (10). http://dx.doi.org/10.1002/ggge.20273.

697 Lonsdale, P., 2005. Creation of the Cocos and Nazca plates by fission of the Farallon 698 plate. Tectonophys. 404 (3-4), 237-264.

699 Mahoney, J. J., Coffin, F. F., 1997. Large Igneous Provinces: Continental, oceanic, and 700 planetary flood volcanism, Washington. Am. Geophys. Union Mono. 100. $701 \quad$ http://dx.doi.org/10.1029/GM100.

702 Matzen, A.K., Baker, M.B., Beckett, J.R., Stolper, E.M., 2013. The temperature and 703 pressure dependence of nickel partitioning between olivine and silicate melt. $704 \quad$ J. Petrol. 54, 2521-2545.

705 Meschede, M., Frisch, W., 1994, Geochemical characteristics of basaltic rocks from 706 the Central American ophiolites. Profil. 7, 71-85.

707 Morgan W. J., 1971. Convection plumes in the lower mantle. Nature 230, 42-43.

708 Morgan, J. P., 2001. Thermodynamics of pressure release melting of a veined plum 709 pudding mantle. Geochem. Geosphys. Geosys. 2, 2000GC000049.

710 McDonough, W., 1991. Partial melting of subducted oceanic crust and isolation of its 711 residual eclogitic lithology. Phil. Trans. Royal Soc. London. Series A. Physical 

and Engineering Sciences. 335 (1638), 407-418.

713 Min K., Mundil R., Renne P. R., Ludwig K. R., 2000. A test for systematic errors in $714 \quad{ }^{40} \mathrm{Ar} /{ }^{39} \mathrm{Ar}$ geochronology through comparison with $\mathrm{U} / \mathrm{Pb}$ analysis of a $1.1 \mathrm{Ga}$ 715 rhyolite. Geochem. Cosmochem. Acta. 64, 73-98.

716 Morgan, W. J., 1972. Deep Mantle Convection Plumes and Plate Motion. Am. Assoc. 717 Petrol. Geol. Bull. 56 (2), 203-213.

718 Naumann, T.R., Geist, D.J., 2002. Petrology and Geochemistry of Cerro Azul Volcano 719 and the Origin of the Petrologic Diversity of the Western Galápagos Shield 720 Volcanoes: An inter-volcano comparison of Cerro Azul, Alcedo, and Sierra $721 \quad$ Negra. J. Petrol. 43, 859-883.

722 Nolet, G., Karato, S., Montelli, R., 2006. Plume fluxes from seismic tomography. Earth $723 \quad$ Planet. Sci. Lett. 248 (3-4), 685-699.

724 O'Connor, J. M., Stoffers, P., Wijbrans, J. R., Worthington, T. J., 2007. Migration of 725 widespread long-lived volcanism across the Galápagos Volcanic Province: 726 Evidence for a broad hotspot melting anomaly? Earth Planet. Sci. Lett. 263 727 (3-4), 339-354.

728 O’Donnell, T. H., Presnall, D.C., 1980, Chemical Variations of the Glass and Mineral 729 Phases in Basalts Dredged from 25-Degrees-30-Degrees-N Along the Mid$730 \quad$ Atlantic Ridge. Am. J. Sci. 280, 845-868.

731 O'Hara, M.J. 1968, The bearing of phase equilibria studies in synthetic and natural systems on the origin of basic and ultrabasic rocks. Earth Sci. Rev. 4, 69-133. 
733 Pertermann, M., Hirschmann, M.M., 2003. Anhydrous partial melting experiments on

734

735

736

737 Pindell, J. L., Barrett, S. F., 1990. Geological evolution of the Caribbean region: a plate 738 MORB-like eclogite: phase relations, phase compositions and mineral-melt partitioning of major elements at 2-3 GPa. J. Petrol. 44, 2173-2201. tectonic perspective: The Caribbean region. In: Dengo, G., Case, J.E., (Eds.), Boulder, Colorado, Geological Society of America, The Geology of North America, H, pp. 405-432.

Richards, M. A., Duncan, R. A., Courtillot, V. E., 1989. Flood basalts and hot-spot tracks: Plume heads and tails. Science. 246 (4926), 103-107.

Ricolleau, A., Perrillat, J.-P., Fiquet, G., Daniel, I., Matas, J., Addad, A., Menguy, N., Cardon, H., Mezouar, M., Guignot, N., 2010. Phase relations and equation of state of a natural MORB: implications for the density profile of subducted oceanic crust. J. Geophy. Res. 115, B08202, doi:10.1029/2009JB006709.

Rudnick, R. L., Barth, M., Horn, I., McDonough, W. F., 2000. Rutile-bearing refractory eclogites: missing link between continents and depleted mantle. Science. 287 (5451), 278-281.

Rudnick, R.L., Gao, S., 2003. The Composition of the Continental Crust, In: Holland, H.D. and Turekian, K.K. (Eds.), Treatise on Geochemistry, Elsevier-Pergamon, Oxford. 3, pp. 1-64.

Saunders, A. D., 2005. Large Igneous Provinces: Origin and Environmental Consequences. Elements. 1, 259-263.

Sinton, C. W., Duncan, R. A., Denyer, P., 1997. Nicoya Peninsula, Costa Rica: A single 
suite of Caribbean oceanic plateau magmas. J. Geophys. Res. 102 (B7), 1550715520.

758 Sinton, C. W., Duncan, R. A., Storey, M., Lewis, J., Estrada, J. J., 1998. An oceanic flood 759 basalt province within the Caribbean plate: Earth Planet. Sci. Lett. 155, 221-

760 235.

761 Shorttle, O., Maclennan,J., 2011. Compositional trends of Icelandic basalts: 762 Implications for short-length scale lithological heterogeneity in mantle 763 plumes. Geochem. Geophys. Geosys. 12, Q11008, doi:10.1029/2011GC003748.

765

766

767

768

769

770

771

772

773 Stolper, E., Sherman, S., Michael, G., Baker, M., Seaman, C., 2004. Glass in the 774 775

776 Stracke, A., Hofmann, A. W., Hart, S. R., 2005. FOZO, HIMU, and the rest of the mantle 777 zoo: Geochem. Geophys. Geosyst. 6 $(5)$. http://dx.doi/10.1029/2004GC000824. 
779 Straub, S.M., LaGatta, A.B., Pozzo, A.L.M.-D. Langmuir, C.H., 2008. Evidence from

780

781

782

783

784

785

786

787

788

789

790

791

792

793

794

795

796

797

798

799

800

801

high Ni olivines for a hybridized peridotite/pyroxenite source for orogenic andesites from the central Mexican Volcanic Belt. Geochem. Geophys. Geosys. 9, Q03007, doi: 10.1029GC001583.

Thompson, G., Bryan, W.G., Melson, W.G., 1980. Geological and geophysical investigation of the Mid-Cayman-Rise-Spreading-Center - geochemical variation and petrogenesis of basalt glasses. J. Geol. 88 (1), 41-55.

Toplis, M. J., 2005. The thermodynamics of iron and magnesium partitioning between olivine and liquid: criteria for assessing and predicting equilibrium in natural and experimental systems. Contrib. Mineral. Petrol. 149 (1), 22-39.

Tolstikhin, I., Hofmann, A. W., 2005. Early crust on top of the Earth's core. Phys. Earth Planet. Interiors. 148 (2-4), 109-130.

Torsvik, T. H., Burke, K., Steinberger, B., Webb, S. J., Ashwal, L. D., 2010. Diamonds sampled by plumes from the core-mantle boundary. Nature. 466 (7304), 352355.

Vidito, C., Herzberg, C., Gazel, E., Geist, D., Harpp, K., 2013. Lithological structure of the Galápagos Plume. Geochem. Geophys. Geosyst. 14 (10). http://dx. doi.org/10.1002/ggge.20270.

Walter, M. J.,1998. Melting of Garnet Peridotite and the Origin of Komatiite and Depleted Lithosphere, J. Petrol., 39 (1), 29-60.

Wegner, W., Worner, G., Harmon, R.S., Jicha, B.R., 2010. Magmatic history and evolution of the Central American Land Bridge in Panama since Cretaceous times. Geol. Soc. Am. Bull. 123, 703-724. 
802 Werner, R., and Hoernle, K., 2003. New volcanological and volatile data provide 803 strong support for the continuous existence of Galápagos Islands over the 804 past 17 million years. Int. J. Earth Sci. 92 (6), 904-911.

805 White, W. M., Albarede, F., Telouk, P., 2000. High-precision analysis of Pb isotope 806 ratios by multi-collector ICP-MS. Chem. Geol. 167, 257-270.

807 White, W. M., McBirney, A. R., Duncan, R. A., 1993. Petrology and geochemistry of the 808 Galápagos Islands: Portrait of a pathological mantle plume. J. Geophys. Res. 809 98 (B11), 19533-19563.

810 Zindler, A., Hart, S., 1986. Chemical Geodynamics. Ann. Rev. Earth Planet. Sci. 14, $811 \quad 493-571$.

812

813 FIG. CAPTIONS

814

815 Fig. 1. A) Tectonic location of the study area (modified from Denyer and Gazel, 816 2009). B) Map of the accreted oceanic complexes along the coast of Costa Rica and 817 Panama (modified from Denyer and Gazel, 2009). C) Geological map of the Quepos 818 terrane showing sample locations, structures, and areas comprised by basalts and 819 picrites modified from Duran (2013).

820

821 Fig. 2. A) Chemical classification of samples using the total alkali versus silica 822 diagram (TAS). Literature data from Meschede and Frishe (1994), Sinton et al. 823 (1997), and Hauff et al. (2000b). B) CaO-MgO discrimination diagram between 824 peridotite and pyroxenite derived magmas from Herzberg and Asimow (2008). This 
825 model was developed for accumulated fractional melting of peridotite KR4003, and

826 is validated by the fact that no experimental melt compositions from a pure

827 peridotite source plot below the discrimination line. The grey shaded region 828 represents primary magmas of fertile peridotite produced by accumulated 829 fractional melting. Additional data from Stolper et al. (2004) for Mauna Kea and 830 from White et al., 1993; Hauff et al., 1997; Allan and Simkin, 2000; Hauff et al., 831 2000a,b; Hoernle et al., 2000; Blichert-Toft and White, 2001; Geist et al., 2002;

832 Naumann et al., 2002; Werner et al., 2003; O'Connor et al., 2007; Wegner et al., 2010

833 for Galápagos related lavas including accreted terranes in Central America and parts 834 of the CLIP including Nicoya and Curacao.

835

836 Fig. 3. Multi-element spider diagram normalized to primitive mantle (McDonough 837 and Sun, 1995). Note how the new data from Quepos overlap with the current 838 Galápagos tracks; the Cocos, Carnegie, and Coiba Ridges. Additional data from White 839 et al., 1993; Hauff et al., 1997; Allan and Simkin, 2000; Hauff et al., 2000; Hoernle et 840 al., 2000; Blichert-Toft and White, 2001; Geist et al., 2002; Naumann et al., 2002; 841 Werner et al., 2003; O'Connor et al., 2007; Wegner et al., 2010 for Galápagos 842 Domains.

843

844 Fig. 4. Mg-numbers versus $\mathrm{Ni}$ and $\mathrm{Ca}$ contents and $\mathrm{Fe} / \mathrm{Mn}$ for calculated olivines and 845 high-precision olivines from $\sim 90$ Ma Curacao picrites. A Mg-number is defined as $846100 \mathrm{MgO} /(\mathrm{MgO}+\mathrm{FeO})$ in mole per cent. Black forms $=$ calculated $\mathrm{Ni}$ and $\mathrm{Ca}$ in 847 olivines that crystallize from all primary melts derived from a fertile peridotite 
848 source having 1960 ppm Ni, 3.45 wt\% CaO and 0.13 wt\% MnO (Herzberg, 2011a);

849 the grey field in panel A represents $\pm 1 \sigma$ uncertainty for Ni (Herzberg et al., 2013).

850 The Curacao primary magma composition was computed from lava sample

851 CR372T92 reported by Klaver (1987). The full range of model olivine Ca for

852 peridotite-source melts far exceeds the $1700-2000$ ppm range that is typically

853 observed for MORB, komatiite, and other olivines of a peridotite source provenance;

854 similarly the upper Fe/Mn model bound of 70 exceeds Fe/Mn of observed olivines

855 of a peridotite source provenance. Curacao olivine compositions define trends

856 towards peridotite-source olivines (see text).

857

858 Fig. 5. Mg-numbers versus $\mathrm{Ni}$ and Ca contents and Fe/Mn for calculated olivines and 859 high-precision olivines from picrites of the $\sim 70$ Ma Quepos terrane. Examples of

860 olivines from a peridotite source primary magma and its derivatives are given by

861 the green cross and arrow, computed from lava sample CR372T92 reported by

862 Tournon (1984). Quepos olivine compositions are not consistent with derivation

863 from a normal peridotite source. Notice how the new Quepos data is within range of

864 Mauna Kea data from Sobolev et al. (2007) interpreted as olivines that crystallized

865 from a pyroxenite-derived primary magma. The trends can be explained by complex

866 olivine+clinopyroxene fractional crystallization or magma recharge (Supplementary

867 Materials for detailed information). Independent of the explanation, these

868 crystallization trends do not extrapolate to peridotite source primary magmas. 869

870 Fig. 6. Source projected $\mathrm{Pb}$ and $\mathrm{Nd}$ isotopes of picrite and basalt samples from the 
871 CLIP and Quepos terrane. Most Quepos samples fall within the Central Galápagos

872 Domain. Shaded Galápagos Domains for the present day archipelago from Hoernle 873 et al. (2000).

874

875 Fig. 7. A) Galápagos plume secular cooling curve modified from Herzberg and Gazel, 876 (2009) using a least squares approximation. Note the drastic decrease in $\mathrm{T}_{\mathrm{p}}$ from the 877 time of LIP emplacement to approximately 70-60 Ma. The actual $\mathrm{T}_{\mathrm{p}}$ range exhibited 878 for each occurrence like the CLIP at a specific time is typically seen in almost all OIB 879 and LIP occurrences, as reported in Herzberg \& Asimow (2008) and Herzberg \& 880 Gazel (2009); these authors have attributed the $T_{p}$ range as a record of plume 881 thermal heterogeneity, higher $T_{p}$ in the core and lower $T_{p}$ at the periphery. B) 882 Evolution of the $\mathrm{Nb} / \mathrm{Nb}^{*}$ vs. time (Ma) from Galápagos related basalts. $\mathrm{Nb} / \mathrm{Nb}^{*}$ is 883 defined as $N b_{N} / \sqrt{ }\left(T_{N} \times L_{N}\right)$ where $N$ means normalized to a primitive mantle 884 composition from McDonough and Sun, 1995. Average $\mathrm{Nb} / \mathrm{Nb}^{*}$ for MORB is 885 calculated from the average MORB composition from Gale et al., 2013. Color bars 886 behind symbols represent the age range of Galápagos units. Notice as the plume 887 cools down the $\mathrm{Nb} / \mathrm{Nb}^{*}$ ratio increased to a max at $0 \mathrm{Ma}$ (Data from White et al., 888 1993; Hauff et al., 1997; Allan and Simkin, 2000; Hauff et al., 2000; Hoernle et al., 889 2000; Blichert-Toft and White, 2001; Geist et al., 2002; Naumann et al., 2002; 890 Werner et al., 2003; 0'Connor et al., 2007; Wegner et al., 2010). 
A)

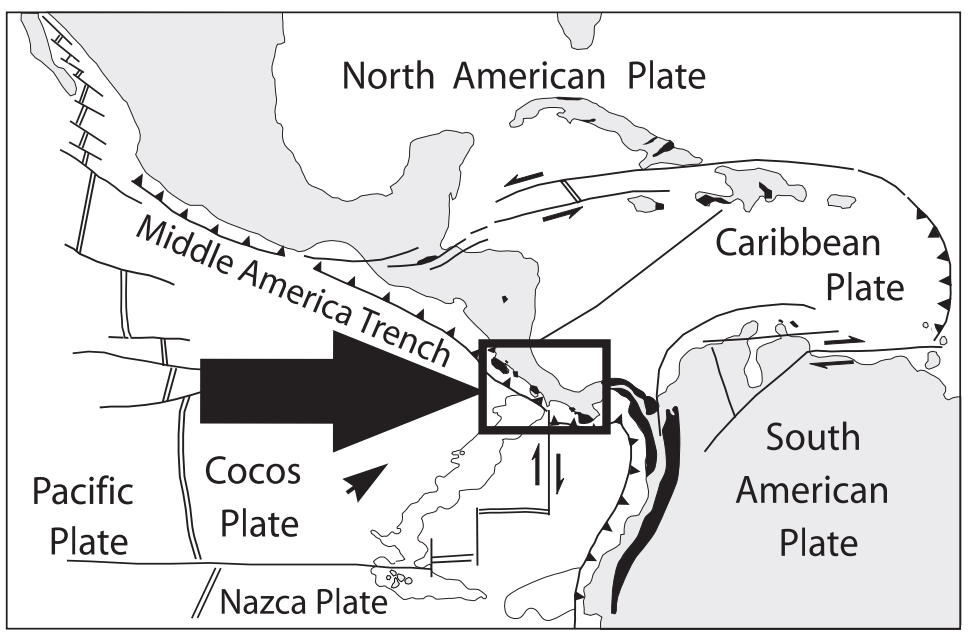

Oceanic Complexes

$\ldots$ Subduction trench

Land mass

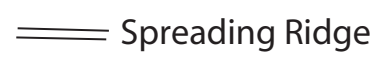

Plate Motion Transform fault

B)

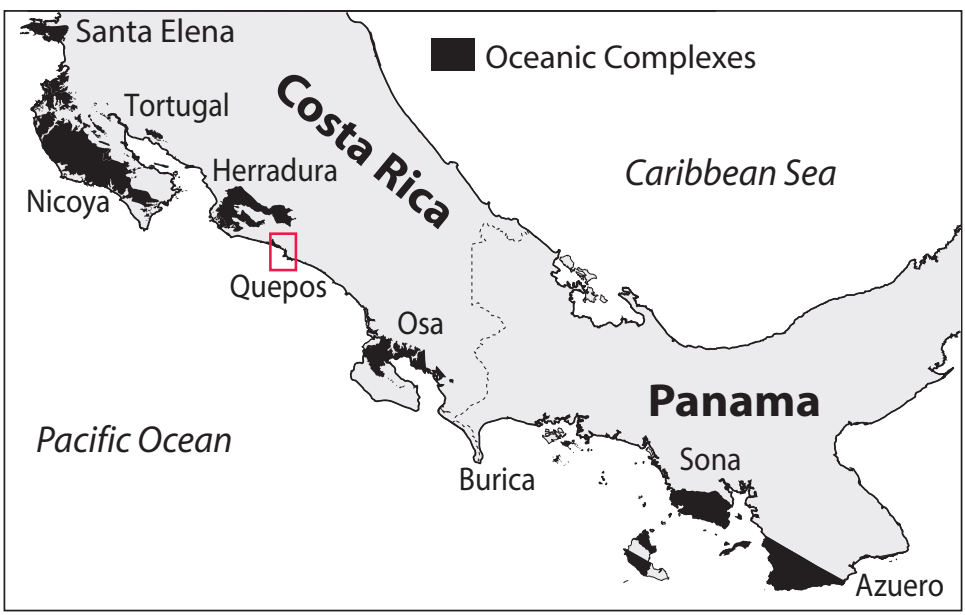

C)

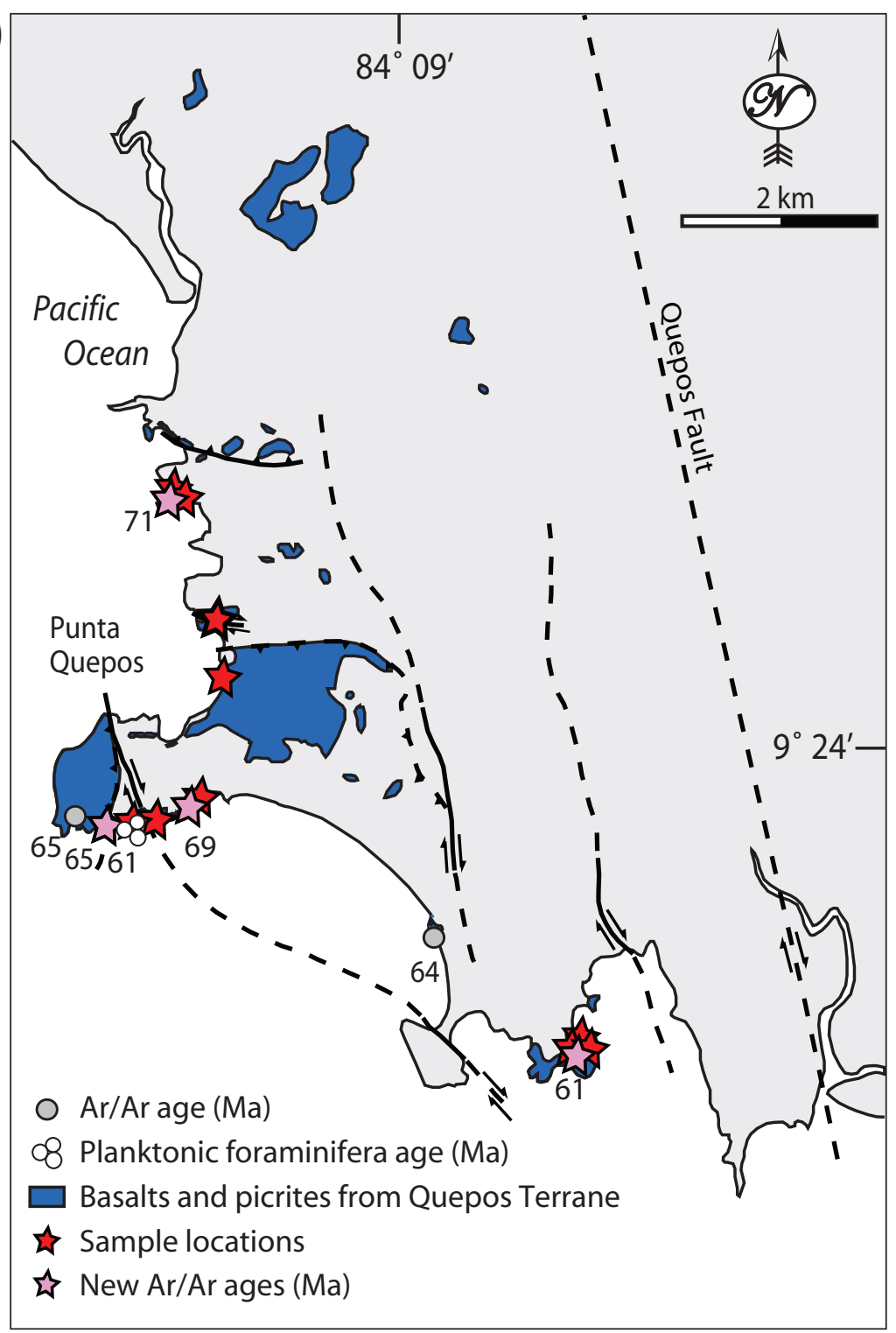


Figure 2

A)

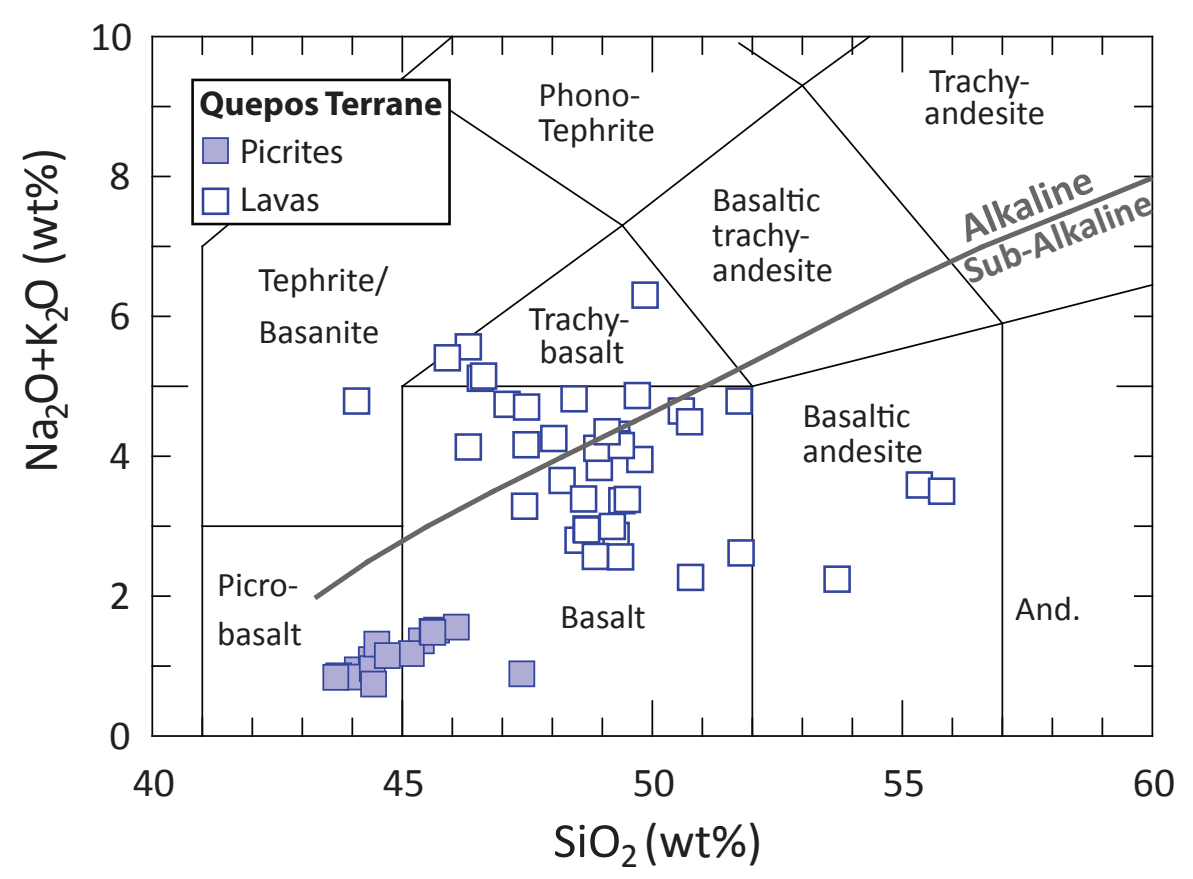

B)

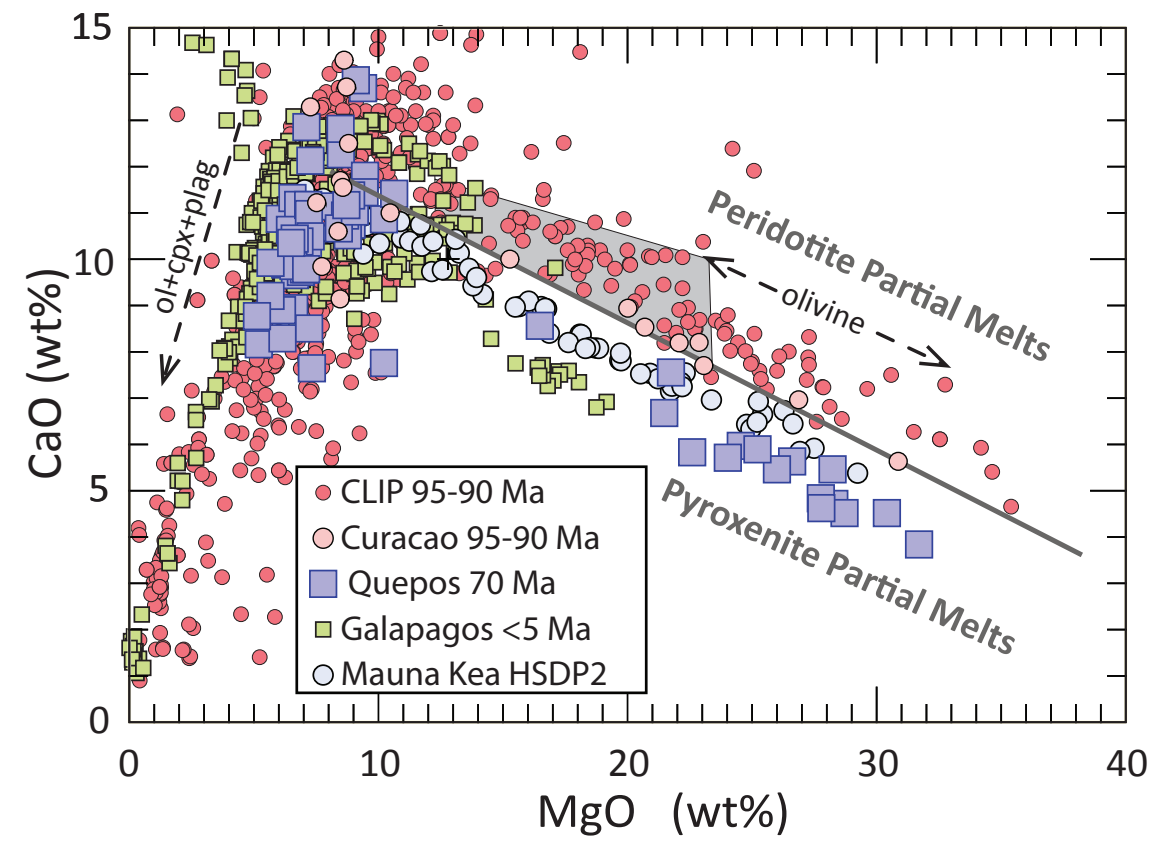




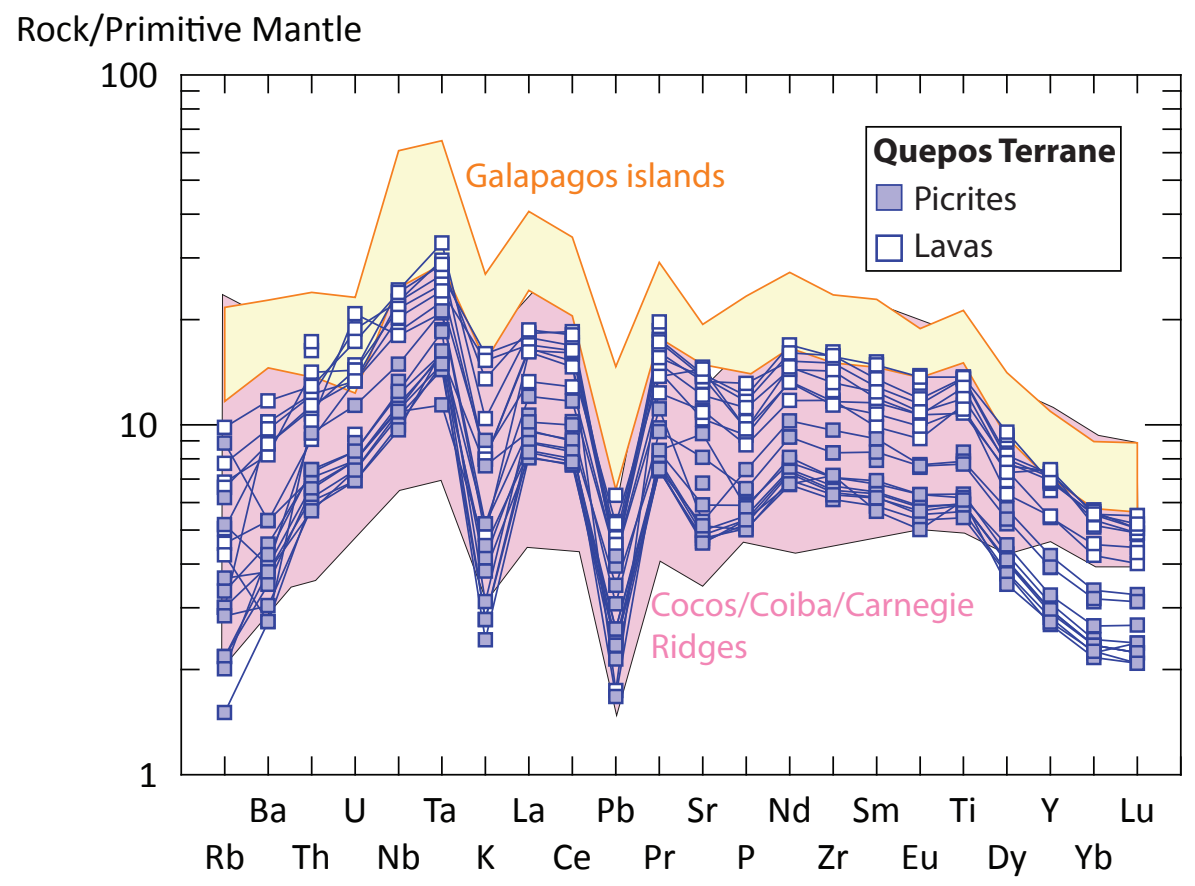


A) 5000

O Curacao $(n=112)$

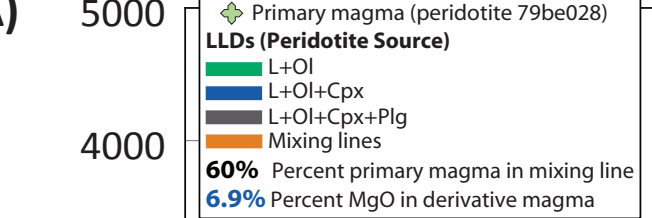

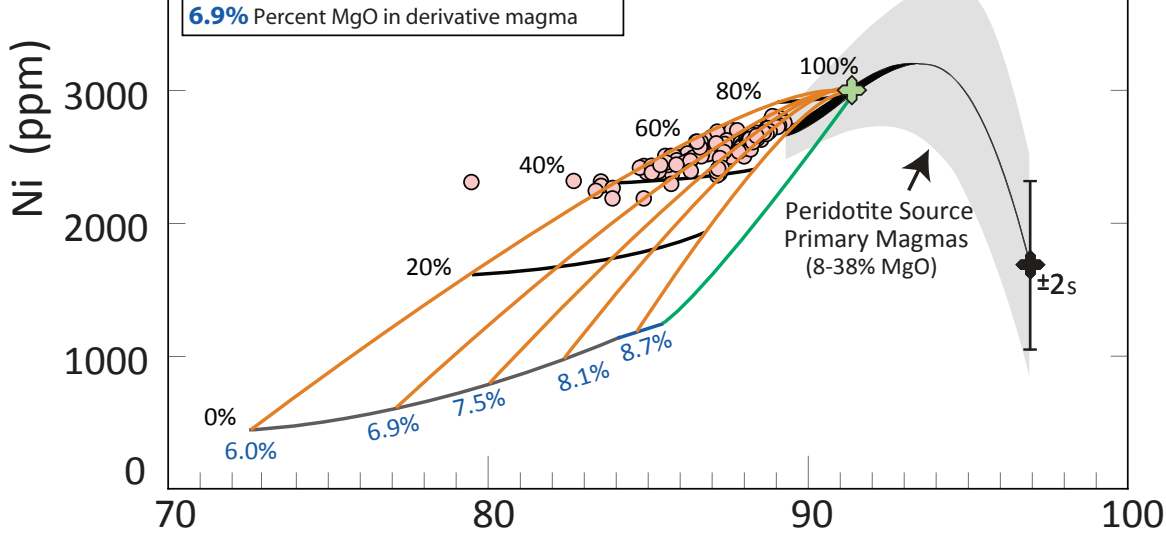

B)

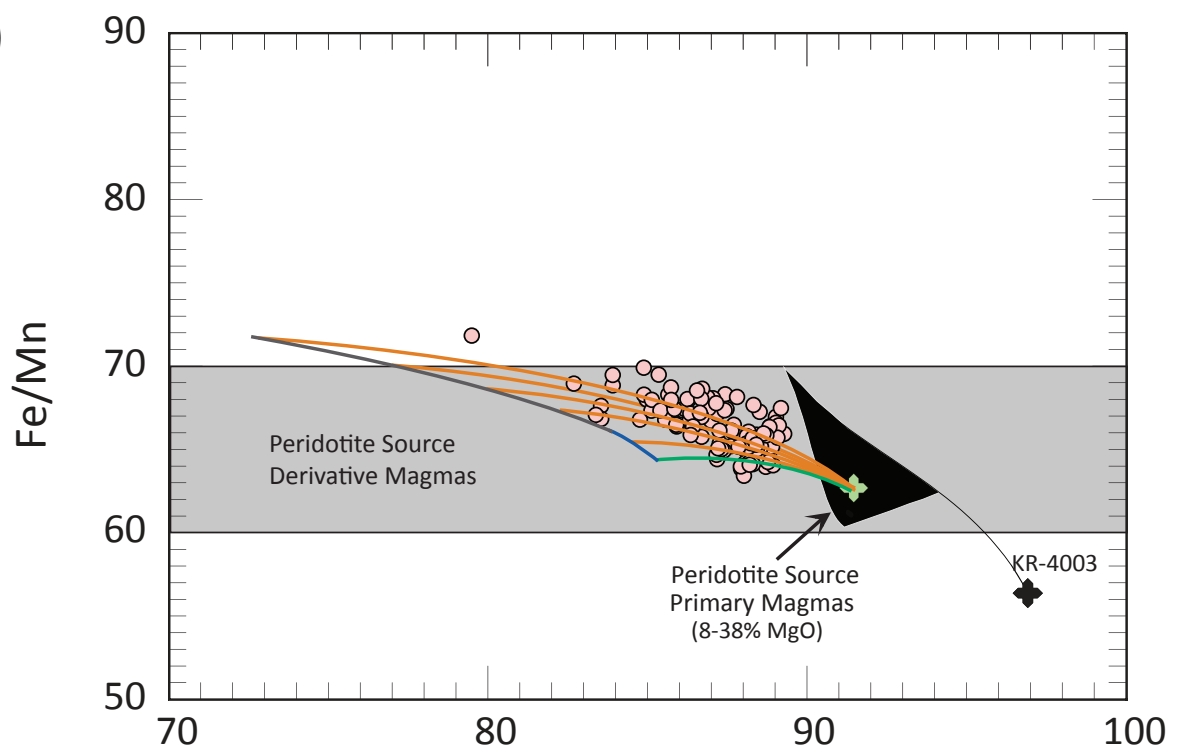

C)

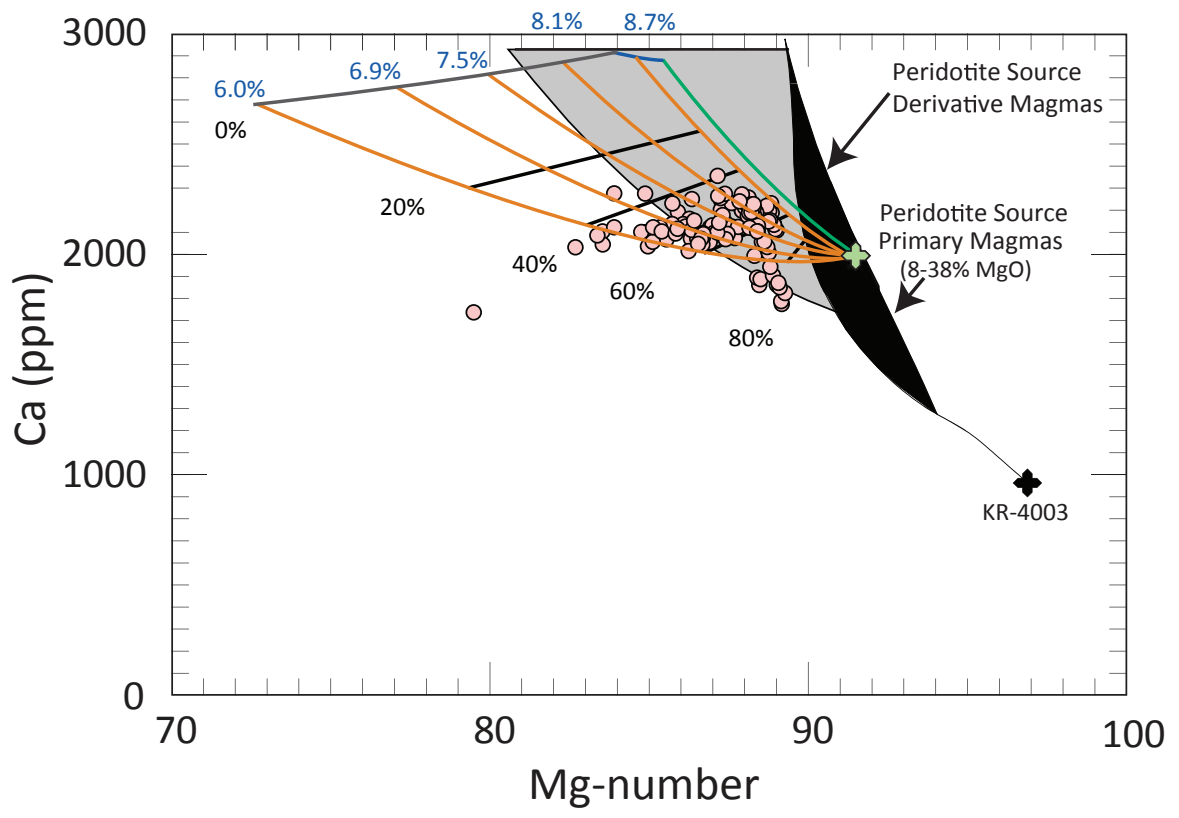


Figure 5

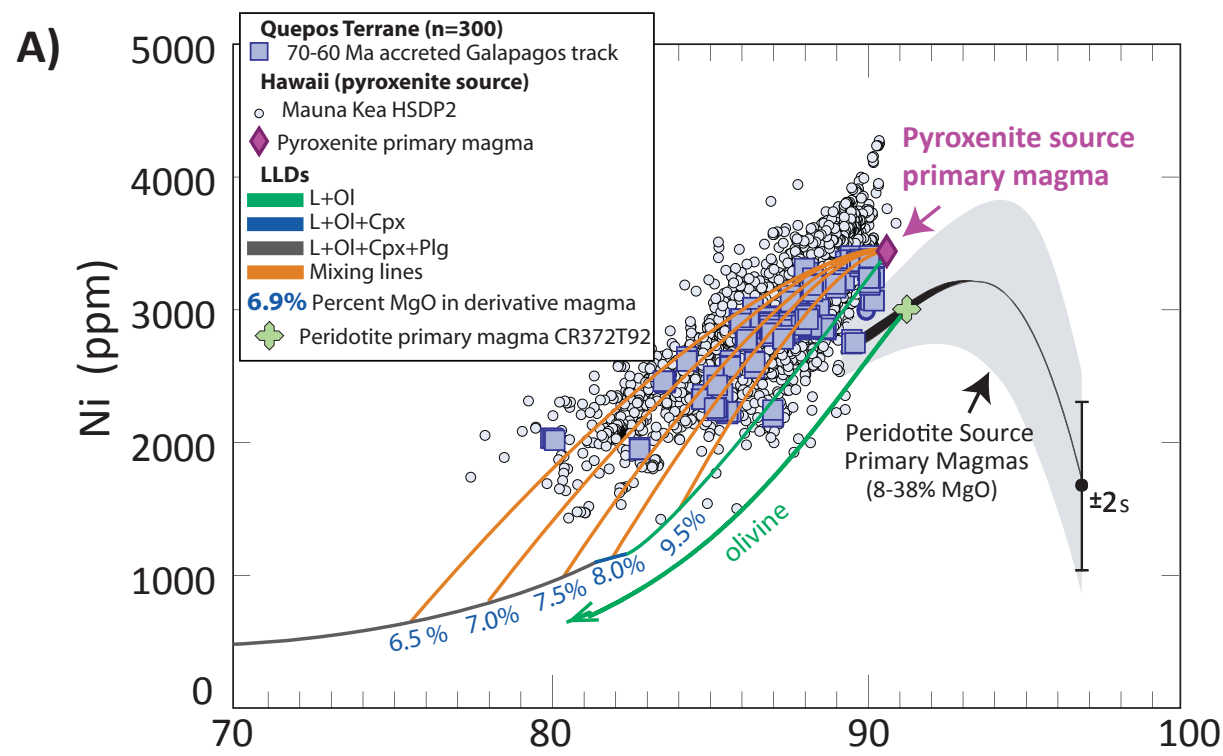

B)

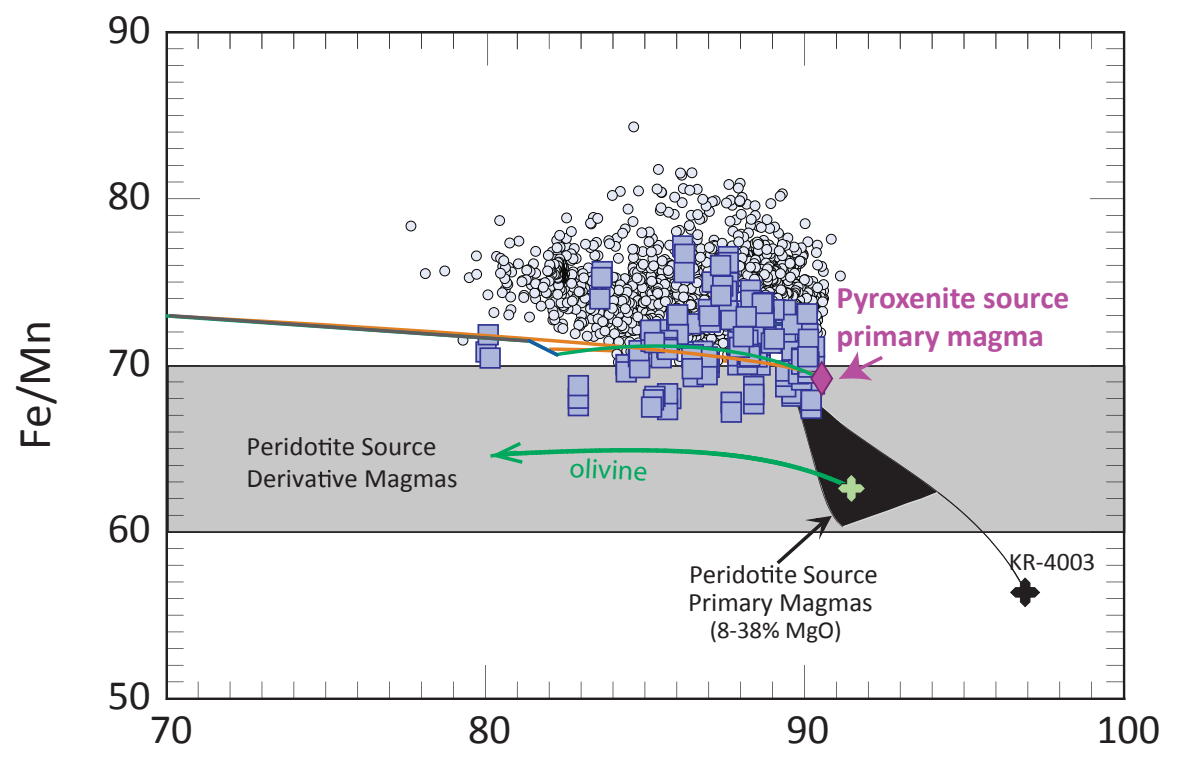

C)

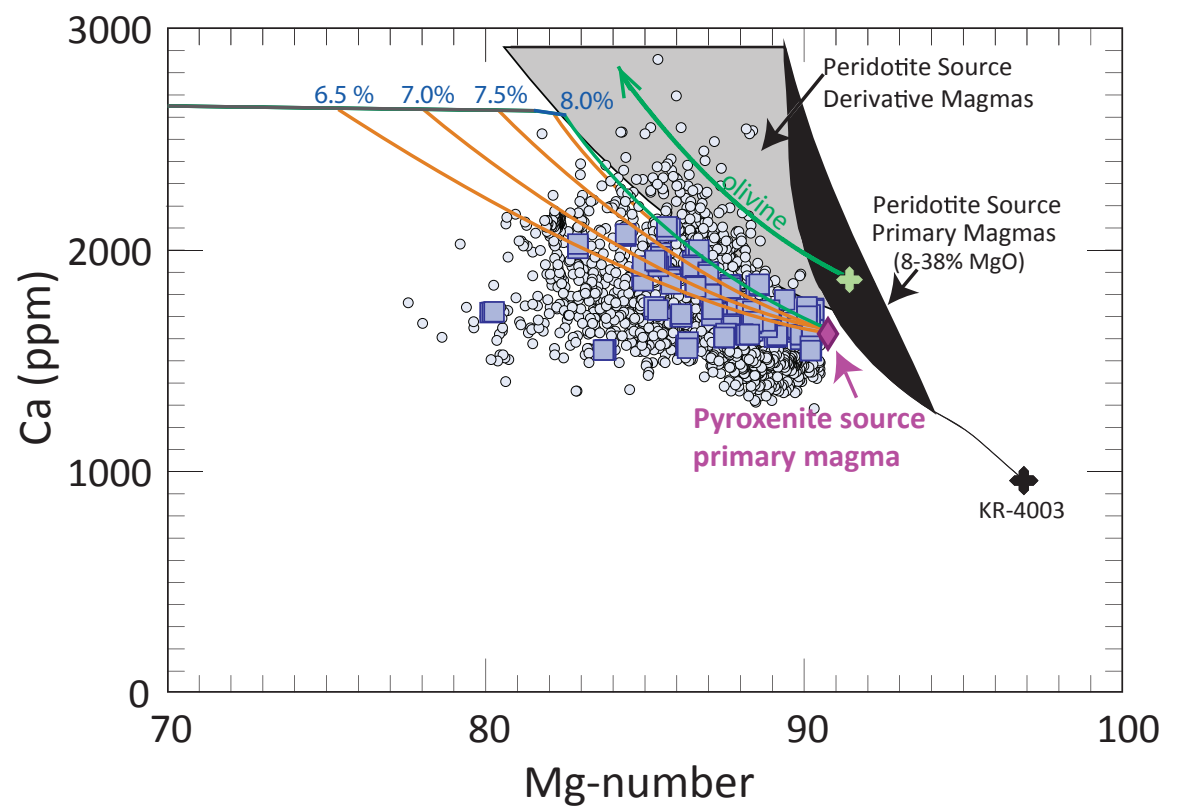



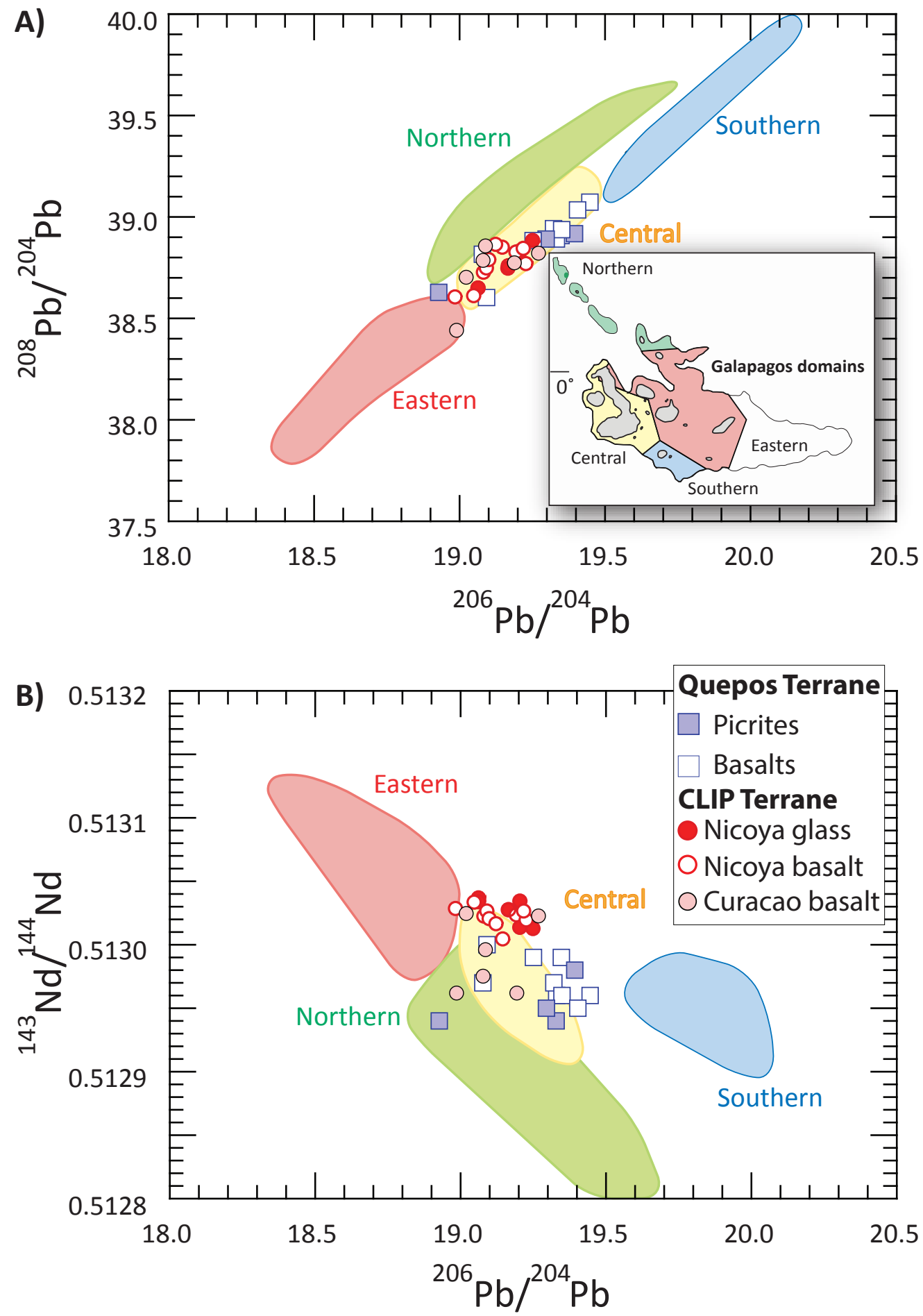
A)

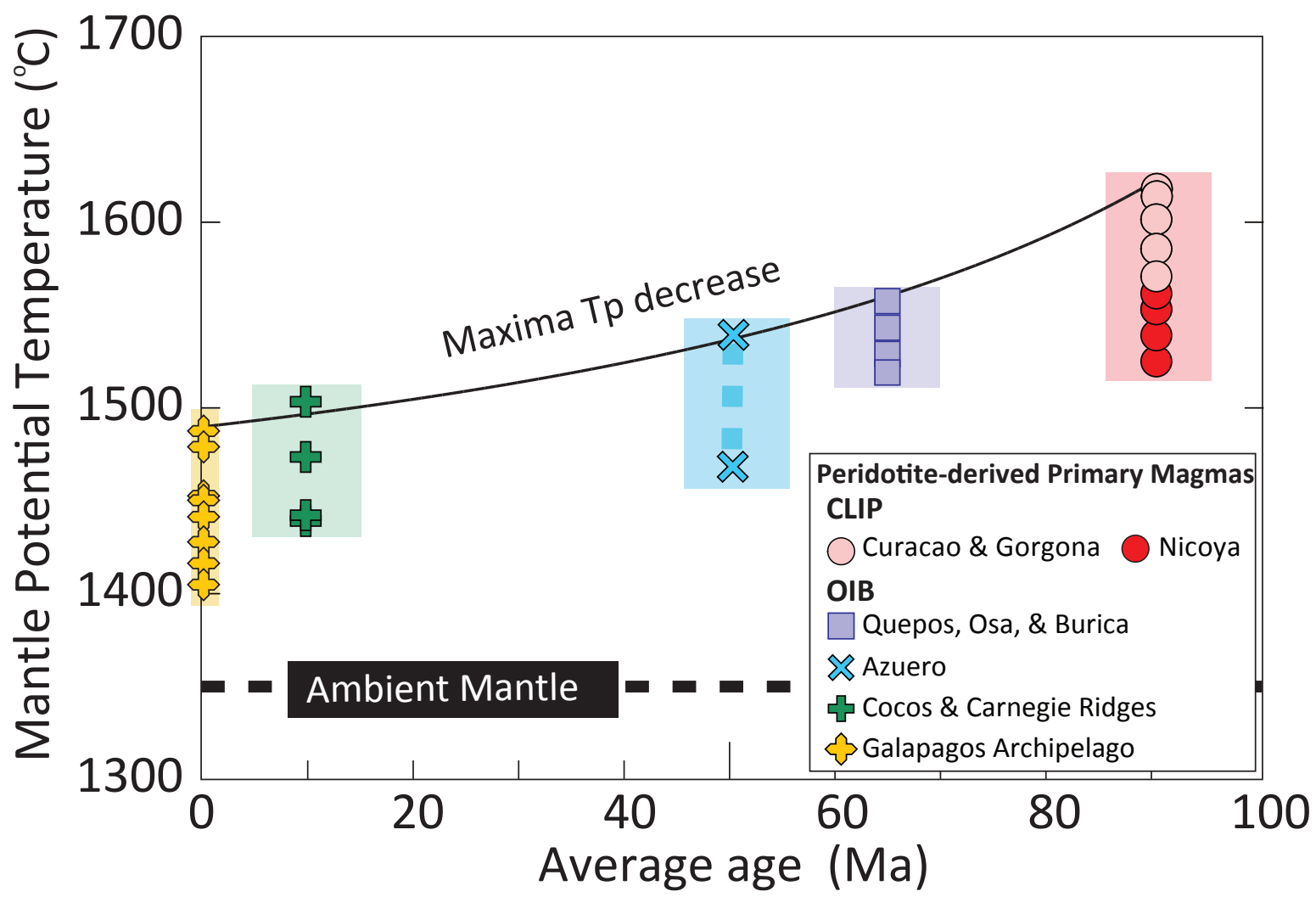

B)

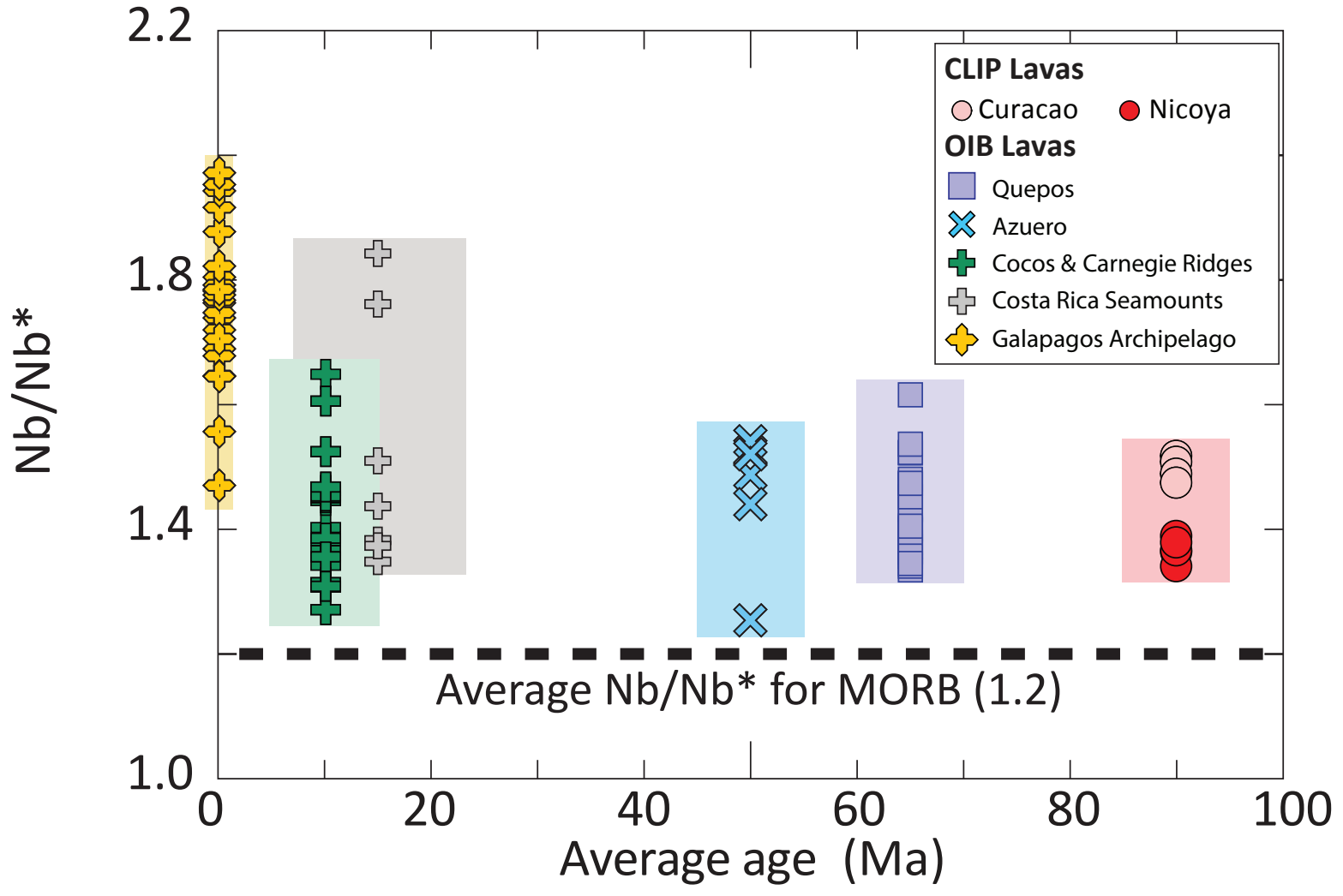

